Article

\title{
Green Bonds, Corporate Performance, and Corporate Social Responsibility
}

\author{
Xiaoguang Zhou *(D) and Yadi Cui \\ Donlinks School of Economics and Management, University of Science and Technology Beijing, \\ Beijing 100083, China; s20180917@xs.ustb.edu.cn \\ * Correspondence: xiaoguang@ustb.edu.cn
}

Received: 13 November 2019; Accepted: 2 December 2019; Published: 3 December 2019

check for updates

\begin{abstract}
Green bonds are a financial tool that has been vigorously promoted in the global green finance field in recent years. Since 2013, the global issuance of green bonds has seen explosive growth. China's green bond market has made great progress, rising to the top tier of global rankings. In this paper, Chinese listed companies that issue green bonds are used as the research object to explore the impact of green bond issuance on companies, including the impact of the announcement of green bond issuance on companies' stock prices, as well as the impact of green bond issuance on companies' financial performance and corporate social responsibility (CSR). The empirical results indicate that announcements of green bonds issuance have a positive impact not only on companies' stock prices, companies' profitability, and operational performance, but also on innovation capacity, and can improve companies' CSR. Overall, the issuance of green bonds has a positive impact on companies, can contribute to environmental improvement, promotes CSR and value creation, and helps to attract investors to some extent.
\end{abstract}

Keywords: green bonds; corporate performance; corporate social responsibility; environmental improvement

\section{Introduction}

Along with the rapid development of the global economy, problems relating to the environment have become increasingly prominent all over the world, and economic growth and sustainable development have become hot topics attracting the attention of most countries [1]. Consequently, there has been more and more research into sustainable development [2-4]. Sustainable development promotes sustainable finance, and this paper examines a practice of financial sustainable development-green bonds. This paper uses Chinese listed companies that have issued green bonds as the research object to explore the impact of green bond issuance on companies, including the impact of the announcements of green bonds issuance on companies' stock prices, as well as the impact of green bond issuance on companies' financial performance and corporate social responsibility (CSR).

Under the umbrella concept of sustainable development, the green economy and green finance, as products of the coordinated development of the economy, society, and the environment in the 21st century, have been the driving force for economic development in the present era. As an effective means of conversion from a carbon-intensive economy to a green economy, low-carbon green development has become the objective of global environmental governance since the 21st United Nations Climate Change Conference of the Parties. Compared with traditional finance, green finance attaches more importance to the relationship between human survival and the environment. In the October 2018 progress report, Network for Greening the Financial System (NGFS) members acknowledged that "climate-related risks are a source of financial risk" [5], which also indicates a strong relationship between environmental changes and green finance. Green finance uses environmental protection 
and a reasonable degree of resource utilization as important standards in measuring the impact of business activities and has resulted in economic entities paying attention to the balanced development of the environment. It emphasizes the coordinated development of financial entities, society, and the environment to ultimately achieve the sustainable development of society. This paper focuses on the economic and environmental benefits of green bonds as a green financial instrument.

The green financial system refers to the institutional arrangement that utilizes financial instruments such as green credit, green bonds, green stock indices and related products, green development funds, green insurance, and carbon finance, as well as relevant policy incentives to support the green transformation of the economy [6]. The use of green bonds as a financial tool has increased significantly in recent years. Since 2013, the global green bond market has experienced explosive growth. The global issuance of green bonds totaled $\$ 11.042$ billion in 2013, rising to $\$ 36.593$ billion in 2014 . The sum of these figures represents about $80 \%$ of all green bonds issued from 2007 to 2014 . Global issuance of green bonds in the first quarter of 2019 maintained this vigorous upward trend, reaching $\$ 47.2$ billion, the highest figure recorded for the first quarter of any year to date. China's green bond market has also developed rapidly. Since the first green bond was issued at the end of 2015, China's green bond market has made great progress, rising to the top tier of the global rankings. Data published by the Climate Bonds Initiative showed that the global issuance of green bonds reached $\$ 167.3$ billion in 2018, of which China accounted for $\$ 30.9$ billion, or $18.5 \%$ of the global total, second only to the United States.

The explosive global growth of green bonds has attracted the attention of not only investors but also scholars [7]. Various scholars have begun to study the definitions and standards [8], issuance and pricing $[9,10]$, and risks and returns [11,12] of green bonds. Although green bonds are becoming increasingly popular in many countries as an innovative green finance tool, whether they can embody their vitalities is another matter. Green bonds are usually issued in relation to green industry projects and environmental improvement projects aimed at such things as mitigating the effects of climate change, resource saving, and pollution control. However, it is necessary to consider whether green bonds can achieve environmental benefits while also providing a suitable return on investment. Some scholars have studied the economic and environmental benefits of green bonds [13-16], but their findings are limited to the performance of specific companies and ignore the impact of green bonds on CSR. Our research focus can be divided into three areas. Firstly, we study the impact of green bond issuance on the company's stock price, and then we analyze the reaction of Chinese stock investors to green bond issuance. Secondly, we examine the impact of green bond issuance on corporate profitability, operational performance and innovation ability, and then we evaluate the economic benefits and practical vitality of green bonds. Lastly, we explore the impact of green bond issuance on CSR, and then we evaluate whether the issuance of green bonds will improve the company reputation and CSR in the long term.

\section{Literature Review}

\subsection{Green Bond Issuance and Stock Market Reaction}

Bond financing and stock financing are both forms of direct financing, and are the main sources of capital for companies. They have the same issuer and are therefore affected by the same fundamentals of a company. Thus, a company's performance on the bond market and the stock market is related [17]. Haesen et al. found that past winners in the equity market were future winners in the corporate bond market, verifying the spillover of momentum from stocks to bonds [18]. Kumar and Tsetsekos found that the stock price is significantly affected by announcements that lower the bond rating [19]. Therefore, various bond market indexes have a mutual impact on each other [20], and there are also cross-market correlations. The bond market cannot be independent of the stock market, and thus the behavior of investors in both the bond market and the stock market is correlated. Bond issuance by companies will affect their stock price [21]. Previous studies have mostly focused on advanced markets rather than emerging markets. Kapoor and Pope [22], Lewis et al. [23], and Li et al. [24] examined the 
American market, Abhyankar and Dunning [25] studied the British market, Cheng et al. [26] analyzed the Japanese market, and Martel and Padron [27] focused on the Spanish market. The results regarding market reactions to companies' external financing events were inconsistent. Some studies found that the announcement of companies' financing event has a negative impact on stock price. For example, Miller concluded that from the cash surplus perspective, external financing of any listed company will signal cash-flow problems to the market, thus having a negative impact on investors' decision-making [28]. However, other studies have produced different findings. For instance, Chin and Abdullah found that the issuance of bonds led to bull markets [29].

The purpose of this paper is to discuss the influence of green bond issuance by listed companies on their stock price on the secondary market. This paper assumes that the issuance of green bonds is good news for the stock prices of listed companies in China. Mathews and Kidney believed that the green plan can improve the ability to attract capital and convey the intention of the company to external stakeholders [30]. Reboredo studied the correlations among the green bond market, the stock market, and the national bond market and found a spillover effect between the green bond market and the stock market [31]. Flammer found that the stock market responded positively to announcements of green bonds issuance [15], and the research on stock prices in this paper is directly related to Flammer's study. Baulkaran confirmed this finding and found that shareholders considered green bonds to be a value-added financing tool, as well as a means of reducing risk given that capital raised through issuing green bonds is used for investing in green projects [32]. While the development of green bonds has varied among countries, most previous studies have only focused on developed countries. Given that China is one of the emerging green bond markets, research on the reaction of Chinese investors to green bond issuance can help us to understand the investment preferences of Chinese investors, as well as the correlation between green bonds (as a fixed income investment) and other financial products.

\subsection{Green Bonds and Financial Performance}

The global issuance of green bonds has seen explosive growth since 2013. However, the degree of development of the green bond market and the identification standard of green bonds vary in different countries. With regard to the use and management of green bonds, the screening and evaluation of projects and the reporting and disclosure of information are being gradually developed and improved. Therefore, it is not easy to form a systematic and complete database of available green bonds. The short time period, sample difference, and developing database all bring problems to the quantitative research on green bonds, and thus there has been less quantitative research than qualitative analysis. Presently, there is no unified definition of green bonds in the international community, and hence some scholars have undertaken comparative research on identification standards in relation to green bonds [8]. Pham studied the risks and price fluctuations of green bonds using a multivariate GARCH model [33], while Chiesa and Barua examined the factors affecting green bond issuance from the perspective of suppliers [34]. Hachenberg and Schiereck [9] and Zerbib [10] analyzed the differences between green bonds and traditional bonds in terms of pricing and rates of return. In addition, some scholars have studied the factors affecting the rate of return of green bonds. For example, Wulandari et al. analyzed the impact of liquidity risk on the rate of return of green bonds by controlling for credit risk, specific characteristics of the bonds, and macroeconomic variables [12]. Nanayakkara found that the "green" sign not only provides an incentive for issuers to obtain finance by issuing green bonds but also offers investors the opportunity to diversify their investments [11]. Most existing studies have focused on pricing and differences in the rate of return of green bonds, whereas the purpose of this paper is to study the impact of green bond issuance on corporate economic performance.

For a long time, scholars thought that investment in environmental preservation rarely provided economic benefits to enterprises. However, with the development of economy, more and more researchers have expressed doubts about this conclusion. For example, some studies have found that in some cases corporate investment and financing decisions can achieve win-win outcomes for both the environment and the company [35-38]. Furthermore, scholars now believe that corporate green 
attributes and competitiveness can coexist [39]. Therefore, some scholars have undertaken quantitative studies verifying that "green" practices can definitely bring profits to companies. For example, Hart and Ahuja found that a reduction in polluting emissions to a minimum within one or two years of the project's commencement can increase benefits to companies [40]. King and Lenox conducted a study using 652 manufacturing companies as the research object and found a clear correlation between low pollution and high financial valuation [41]. Horvathova stated that if corporate stakeholders display environmental preferences, CSR behaviors can enable a company to achieve rates of return that are significantly greater than zero [42]. It has been shown that efforts by companies to improve their environmental performance can definitely improve their financial performance [43]. Miroshnychenko et al. proved that green practices were positively associated with companies' future market value and profitability. In particular, pollution prevention and green supply chain management were the main environmental factors driving financial performance [44]. Our research on green bonds and corporate performance is directly related to the studies of Aguilera-Caracuel and Ortiz-De-Mandojana [45] and Zerbib [16]. We assume that the issuance of green bonds exerts a positive influence on economic benefits. In other words, green bonds issuance can improve the company's financial performance, profitability, technological innovation, and other aspects. Aguilera-Caracuel and Ortiz-De-Mandojana found a positive correlation between the degree of green innovation and profitability [45]. At present, green bonds are mainly issued for the purpose of raising capital for low-carbon projects or green schemes. Whether green bonds provide economic benefits and improve the financial performance of the issuer is worthy of researchers' attention. Zerbib [16] found that investors attracted by the "green" sign do not play a significant role in promoting the development of green bonds. If green bonds only make use of the "green" sign and fail to improve the financial performance of enterprises, they are not true to their name, and are merely a form of "greenwashing". Flammer [15] and Queen [14] examined the impact of the issuance of green bonds on the financial performance of the issuing companies, with the former finding that green bond issuance results in economic benefits and can improve corporate financial performance [15]. China is now the second largest green bond issuance market in the world, and thus further research on the impact of green bond issuance on the financial performance of Chinese companies will contribute to our understanding of the economic benefits of green bonds.

\subsection{Green Bonds and CSR}

CSR integrates a diverse set of requirements for the company's long-term development and has attracted considerable attention in recent decades. Carroll defined CSR as the social responsibility of business encompassing the economic, legal, ethical, and discretionary expectations that society has of organizations at a given point in time [46]. Clarkson pointed out that the economic and social purpose of the corporation is to create and distribute increased wealth and value to all of its primary stakeholder groups, without favoring one group at the expense of others [47]. Based on this view, companies must transcend the traditional concept of profit as their sole objective and stress the importance of human, social, and environmental values, ensuring that their activities contribute to the protection of the environment, consumers, and society. Research has shown that companies that undertake CSR activities can achieve better financial performance [48-50]. In addition, studies have identified positive correlations among CSR, the environment, and society [51-53]. Flammer found that CSR has a significantly positive impact on companies' stock prices [15,52]. Cho et al. found a significant correlation between the level of CSR and information asymmetry. Companies can positively influence investor perception by reducing information asymmetry [54]. Thus, companies with a high level of CSR may benefit both financially and in terms of their perception by society, achieving a win-win outcome.

To date, there are few studies examining the correlations among green bond issuance, CSR, and environmental performance. This paper considers the impact of green bond issuance on CSR from two perspectives. One is the issuance significance. The issuance of green bonds is conducive to showing the public companies' determination to develop into environment-friendly enterprises and their social responsibilities. Another is the issuance costs. The issuance of green bonds reduces a 
company's financing costs and improves the efficiency of using resources, and thus helps the company to provide products and services for the society, to fulfill its social responsibilities. Wang and Zhi analyzed the relationship between green finance and environmental protection and proposed a scheme that would enable green finance to provide better environmental protection [55]. This indicates that green bond issuance embodies the concept of environmentally friendly enterprises. Huang et al. found a negative relationship between CSR and the cost of bonds that was strengthened when the bond issuers were state-owned enterprises or the bond credit rating was high [56]. Chiang et al. stated a correlation between bond ratings and CSR activity levels. Research on the impact of green bond issuance on CSR contributes to research on CSR in China, and thus provides a reference point for relevant companies [57].

\section{Basic Theories and Assumptions}

\subsection{Development of the Green Bond Market in China}

In response to climate change, the World Bank and the Organization for Economic Co-operation and Development (OECD) defined a green bond as a fixed income bond issued by the government, multinational banks, or enterprises for the purpose of raising the necessary capital to promote low-carbon-economy projects and climate change adaptation projects. However, the international community has differing views on the scope of green bonds. It is noted in the Catalogue of Projects Supported by Green Bonds released by the People's Bank of China that green bonds refer to capital raised through the issuance of bonds that is only used to support green industry projects. In this paper, when collecting data on China's green bonds, the standards used for China's green bond indexes compiled through the joint efforts of the China Central Depository \& Clearing Co., Ltd and the China Energy Conservation and Environmental Protection Group Consulting Co., Ltd were taken into consideration.

Since the formal launch of China's green bond market at the end of 2015, both the quantity and value of green bonds have increased. From 2016 to 2018, the number of green bonds issued shows a linear growth trend, as shown in Figure 1.

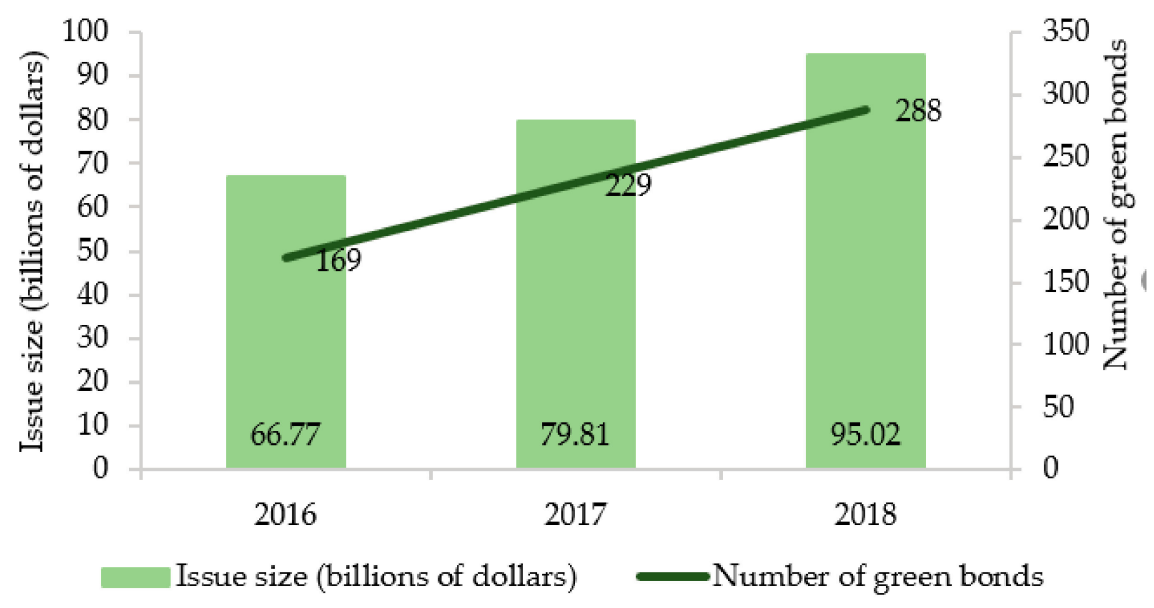

Figure 1. Quantity and value of China's green bonds (Data source: Wind database).

By the first half of 2019, China had issued 908 green bonds. In terms of issuers, most green bonds are issued by non-listed companies. The value of green bonds issued by listed companies accounts for $23.75 \%$ of the total, while the quantity of green bonds issued by listed companies accounts for $25 \%$ of the total, as shown in Figure 2. 


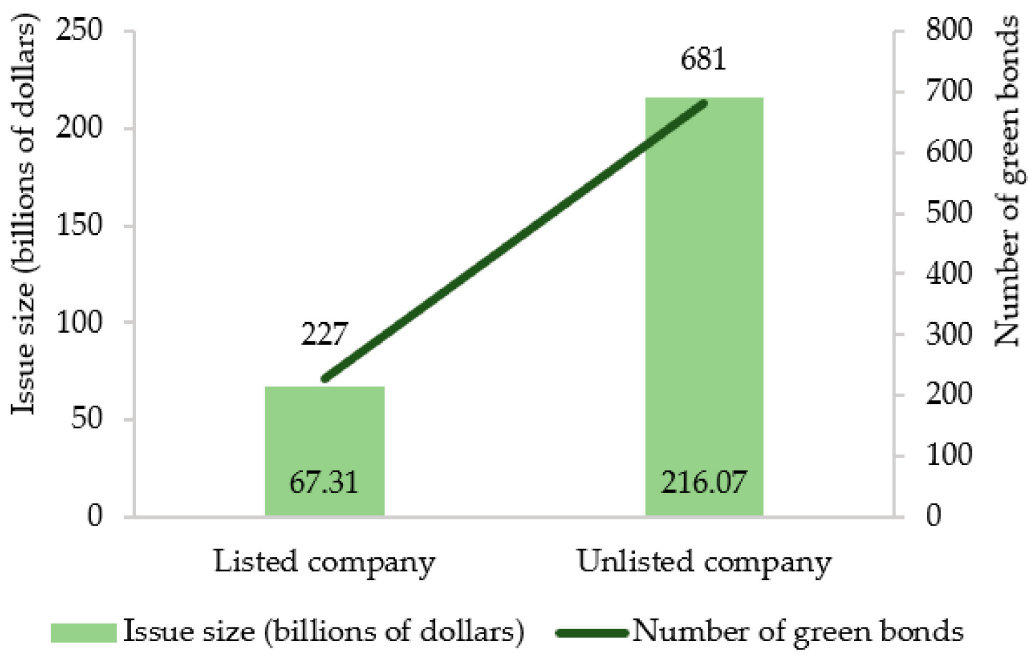

Figure 2. Value and quantity of China's green bonds (by company type) (Data source: Wind database).

In terms of the issuance location, more than two-thirds of green bonds are issued in interbank markets, and the remaining part of green bonds is issued on the Shanghai or Shenzhen Stock Exchange. The number of green bonds issued by the Shenzhen Stock Exchange is far smaller than that issued by the Shanghai Stock Exchange, as shown in Figure 3.

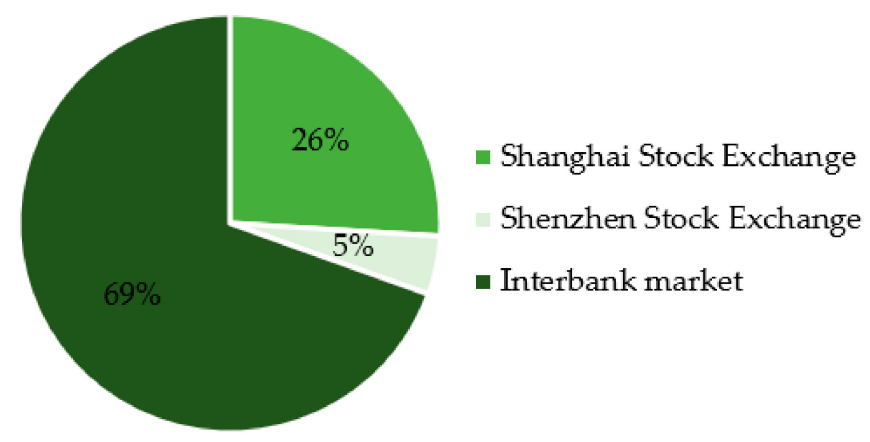

Figure 3. Issuance location of China's green bonds (Data source: Wind database).

In terms of the types of bonds issued, the most common type is green corporate bond, followed by green enterprise bond, together representing $46 \%$ of the total quantity of bonds issued, as shown in Figure 4. As regards to green bonds issued by listed companies, the number of green enterprise bonds is higher than that of other types of bonds, with green enterprise bonds and green corporate bonds together accounting for $44 \%$ of the total quantity of bonds issued by listed companies, as shown in Figure 5.

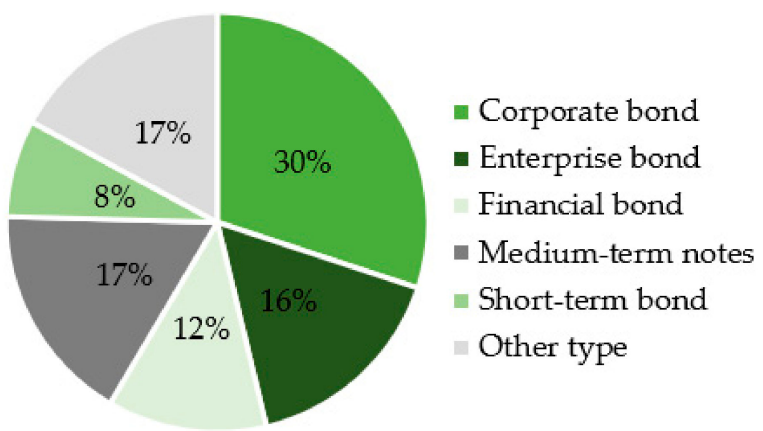

Figure 4. Types of green bonds issued in China (Data source: Wind database). 


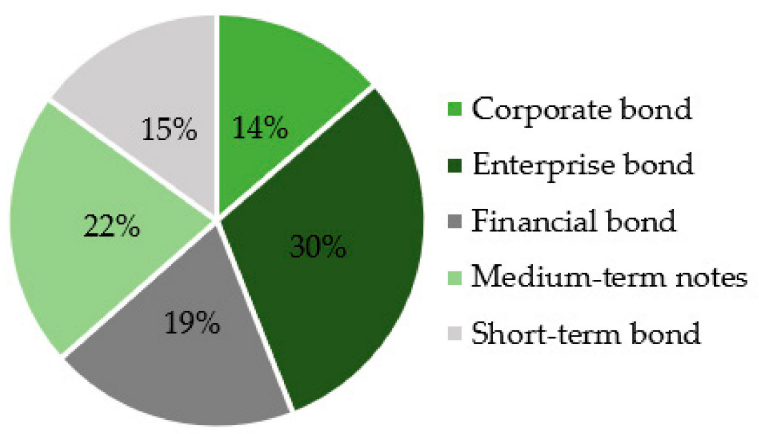

Figure 5. Types of green bonds issued by listed companies in China (Data source: Wind database).

\subsection{Event Study Approach}

The event study approach enables the impact of a specific event on a company to be analyzed using data from the financial markets. Characterized by rigorous theory, clear logic, and simple calculations, the event study approach has been applied in numerous fields to examine the impact of a specific event [58-61].

The main steps in the event study approach are as follows. First, the research object should be specified, that is, the specific event should be identified. Second, samples should be selected based on availability, representativeness, and accuracy to ensure that accurate conclusions with broad significance can be drawn. Third, the estimation window, event window, and post-event window should be specified. The estimation window refers to the specific time frame used to calculate normal returns, i.e., the expected returns that would have occurred within the event window in the absence of the specified event. The selection of the event window is related to the research object (i.e., the degree of influence of an event), and should be specified in accordance with the specific situation. The post-event window enables the long-term impact of an event to be analyzed. The framework of the event study approach is shown in Figure 6.

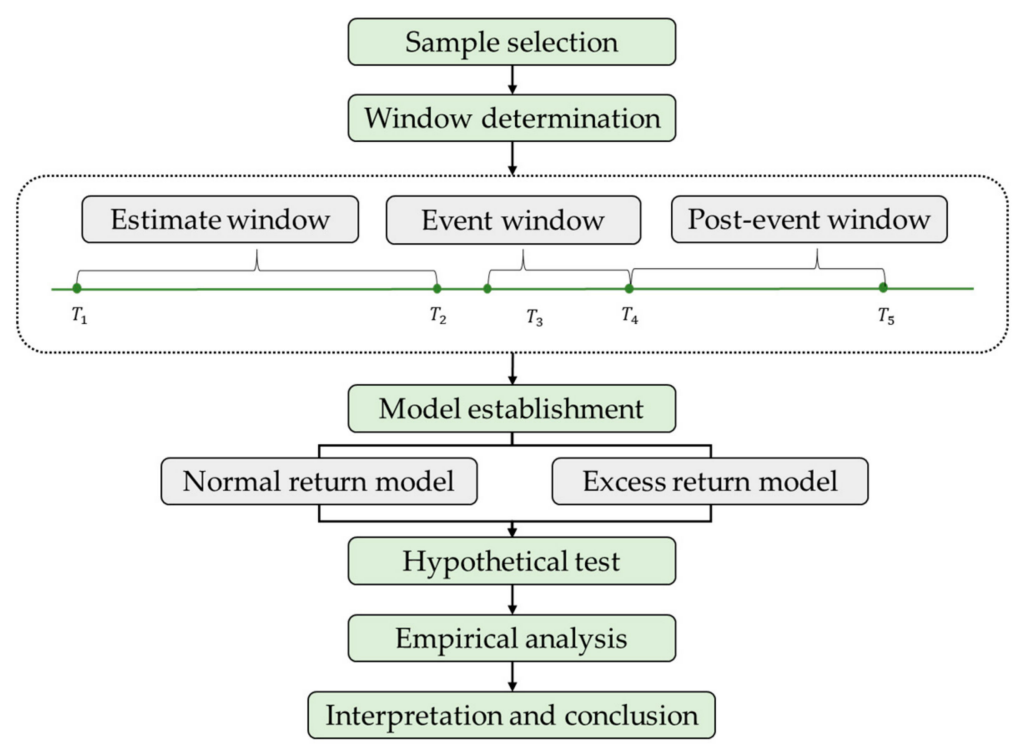

Figure 6. Framework of the event study approach.

In addition, models of normal returns and abnormal returns should be established. There are several kinds of models used to estimate normal returns, and the market model shown in Equation (1) is used in this paper. Abnormal return $(A R)$ refers to the differential return equal to the real return of bonds minus the expected return within the event window. The calculation method is shown in Equation (2). Cumulative abnormal return (CAR) involves the simple addition of the abnormal return 
of each bond within the interval of a specific event, and the calculation method is shown in Equation (3). Average abnormal return $(A A R)$ and average cumulative abnormal return (CAAR) are the mean values of the abnormal returns and cumulative abnormal returns, respectively, and their calculation methods are shown in Equation (4) and Equation (5), respectively.

$$
\begin{gathered}
E(R)_{i, t}=\alpha_{i}+\beta_{i} R_{m, t}+\mu_{i, t}, \\
A R_{i, t}=R R_{i, t}-E(R)_{i, t}, \\
C A R_{i, T}=\sum_{t=t_{1}}^{t=t_{2}} A R_{i, t}, \\
A A R_{t}=\frac{1}{N} \sum_{i=1}^{n} A R_{i, t}, \\
C A A R_{T}=\frac{1}{N} \sum_{i=1}^{n} C A R_{i, T},
\end{gathered}
$$

where $E(R)_{i, t}$ denotes the expected return of listed company $i$ on the $t$ th day, $A R_{i, t}$ denotes the abnormal return of listed company $i$ on the $t$ th day, $R R_{i, t}$ denotes the real return of listed company $i$ on the $t$ th day, $R_{m, t}$ denotes the real return of the comprehensive index $m$ of the stock market where the listed company $i$ was listed on the $t$ th day, $\alpha$ and $\beta$ denote the intercept and slope of the market model, respectively, $\mu_{i, t}$ denotes a random error term of listed company $i$ on the $t$ th day, $C A R_{i, T}$ denotes the cumulative abnormal return of listed company $i$ within the time interval $T\left[t_{1}, t_{2}\right], t_{1}$ and $t_{2}$ represent respectively the initial and final moments in the time interval, $A A R_{t}$ denotes the average abnormal return of all the listed company samples on the th day, $C A A R_{T}$ denotes the cumulative average abnormal return of all the listed company samples within the time interval $T$, and $N$ is the sample size (from 1 to $n$ ).

Usually, the statistical method is used to test the results of the event study approach. The null hypothesis is that the event has no impact on stock prices, while the alternative hypothesis is that the event has an impact on stock prices. $T$-tests are commonly used, and calculation methods are shown in Equation (6) and Equation (7).

$$
\begin{aligned}
T-\text { test }_{A A R_{t}} & =\frac{A A R_{t}}{S\left(A R_{i, t}\right) / \sqrt{N}}, \\
T-\text { test }_{C A A R_{T}} & =\frac{C A A R_{T}}{S\left(C A R_{i, T}\right) / \sqrt{N}},
\end{aligned}
$$

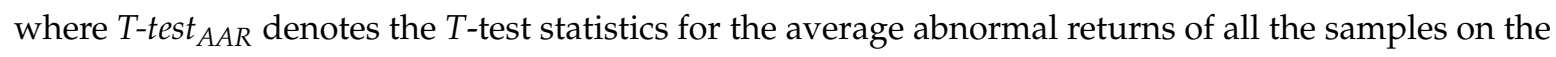
$t$ th day, $T$-test ${ }_{C A A R}$ denotes the $T$-test statistics for the average cumulative abnormal returns of all the samples during the event interval $T, S(A R)_{i, t}$ denotes the standard deviation of abnormal returns of all the samples on the $t$ th day, $S(C A R)_{i, T}$ denotes the standard deviation of cumulative abnormal returns of all the samples within the event interval $T$.

\subsection{PSM and DID}

Propensity score matching (PSM) and difference-in-differences (DID) model has been widely used in many areas, such as policy impact evaluation [62,63], investment performance research [64,65], and environmental governance [66]. PSM is a commonly used statistical method for finding a control group that is most similar in terms of observable characteristics to the treatment group in order to eliminate selection bias. DID is mainly used to evaluate the social impact of a particular policy or event. The principle underlying the DID approach is that changes in observed factors are evaluated in the case of occurrence and non-occurrence based on a counterfactual thinking framework. In reality, 
perfect experimental and control groups in relation to the occurrence of specific events are rare, and thus the applicability of DID needs to be evaluated.

This paper investigates the impact of green bond issuance on the economic benefits of companies. In general, if the issuance of green bonds can be regarded as natural or quasi-experimental, then we can explore the effect of green bonds issuance by comparing the companies issuing green bonds (the treatment group) and the companies not issuing green bonds (the control group). However, direct comparison between companies issuing green bonds and those not issuing green bonds will lead to inaccurate results for the following two reasons:

(1) The company's issuance of green bonds is non-random. For example, companies in water conservancy and environmental protection industries are more willing to issue green bonds to support green projects. Therefore, direct estimation of non-random samples will generate sample selectivity bias.

(2) The partial difference in economic benefits between companies issuing green bonds and those not issuing green bonds may be caused by other factors, and direct comparison may result in heterogeneity bias.

Considering the two above-mentioned factors may influence the results, in order to eliminate the selectivity of samples, this study uses PSM method to find a control group which is similar to the companies issuing green bonds. Then DID method is used to estimate the causal effects of the green bonds issuance, thus ensuring the accuracy of the estimation results to a greater extent. More detailed steps are as follows:

(1) Matching the propensity score of the selected sample

The purpose of matching is to find individuals with similar characteristics to the processing group and construct counterfactual results. Specifically, the samples are divided into two groups in the matching process: One is the treatment group $(T)$, indicating that the companies have issued green bonds; the other group is the control group $(C)$, indicating that the companies have never issued green bonds during the study period. Let $A=\{T, C\}$. Then, $A$ represents all sample companies. The matching method is used to find the companies from the control group that have not issued green bonds and are very similar to the companies issuing green bonds, eliminating the selectivity bias. Suppose the probability equation of issuing green bonds is:

$$
P=\operatorname{Pr}\{A=T\}=\Phi\left(X_{i, t}\right),
$$

where $p$ is the probability of companies issuing green bonds and $\Phi$ is the normal cumulative distribution function. $X_{i, t}$ is a matching variable, indicating that there are $i$ influencing factors at time $t$. The likelihood of green bond issuance was estimated by using a probit model. Then, propensity score matching was used to match companies with similar likelihoods of issuing green bonds. Finally, a control group of companies with similar characteristics to those in treatment group was obtained, represented by $C_{P S M}$.

(2) Using DID method to estimate the effect of issuing green bonds

By means of PSM method, another group of sample companies $A_{P S M}=\left\{T, C_{P S M}\right\}$ was obtained, where $T$ represents the companies issuing green bonds and $C_{P S M}$ represents the companies not issuing green bonds after matching. This paper constructs two virtual variables, "Treated" and "Post". As for Treated, it takes the value of 1 when $i \in T$ and 0 when $i \in C_{P S M}$. As for Post, the value of 1 indicates the time after the green bond issuance, while a value of 0 indicates the time before the green bond issuance. The value of 1 for Treated*Post indicates the performance of companies in the treatment group after 
green bonds issuance. On this basis, the following dual difference model can be constructed as shown in Equation (9):

$$
\text { EcoBen }_{i, t}=\alpha+\beta_{0} \times \text { Treated } * \text { Post }_{i, t}+\beta_{j} \times \sum_{j=1}^{n} X_{i, j, t}+u_{i, t}+\tau_{i, t}+\varepsilon_{i, t},
$$

where $\operatorname{EcoBen}_{i, t}$ is the economic benefit of company $i$ in $t$ th year, $X_{i, j, t}$ indicates other influencing variables, $u_{i, t}$ and $\tau_{i, t}$ represent individual fixed effect and time fixed effect, respectively.

As Abadie [67], Fan and Manzanares [68], and Bouasone and Masaru [69] described the DID models in detail, this paper will not repeat it here. According to the basic idea of DID, the coefficient $\beta_{0}$ of cross-term Treated ${ }^{*}$ Post reflects the change in the economic benefits of companies before and after the issuance of green bonds, which is the main parameter to be estimated in this paper.

\subsection{Hypothesis Analysis}

The announcement of green bonds issuance can convey the company's intention to external stakeholders and thus achieve the purpose of attracting investors. According to Reboredo's research, there is a spillover between the green bond market and stocks [31]. Therefore, we assume that the company's bond announcement will also have some effect on the stock market. Moreover, according to Flammer's research, stock markets react positively to announcements of green bonds issuance [15]. Baulkaran found that shareholders see green bonds as a means of value-added financing [32]. Based on the literature review and theoretical analysis, it is believed that green bond issuance can attract stock investors to some extent. Therefore, announcements of green bond issuance should influence stock market investors to behave more bullishly. In other words, green bond issuance has a positive impact on the stock price of the issuing companies, leading to Hypothesis 1.

Hypothesis $\mathbf{1}\left(\mathbf{H}_{\mathbf{1}}\right)$ : Green bond issuance has a positive impact on the stock price of the issuing companies.

The issuance of green bonds is an effective way to reduce financing costs and broaden financing channels. Miroshnychenko et al. found that green practices were positively associated with companies' future market value and profitability [44]. The research on green bonds and corporate performance in this paper is directly related to the study of Queen [14], Flammer [15], Zerbib [16], and Aguilera-Caracuel and Ortiz-De-Mandojana [45], leading to Hypothesis 2. We assume that the issuance of green bonds exerts a positive influence on economic benefits. In other words, green bonds issuance can improve the company's financial performance, profitability, technological innovation, and other aspects.

Hypothesis $\mathbf{2}\left(\mathbf{H}_{\mathbf{2}} \mathbf{)}\right.$ : Green bond issuance has a positive impact on corporate financial performance.

Green bonds are an innovative financial tool that is aligned with the sustainable development of the economy, society, and the environment. Chiang et al. found that irresponsible CSR activities had a negative impact on companies [57], while Cui et al. found that CSR activities can be used as a tool to establish and maintain the reputation of a company and improve the information environment [70]. Green bonds have both the attributes of "green" and "bond", and the raised funds are used specifically for green projects with environmental benefits, so they could attract the attention of the government and the society. Therefore, from the perspective of social attention, the issuance of green bonds can enable enterprises to get support from the government or the public and form a certain short-term corporate image. In addition, issuing green bonds is a kind of social responsibility participation, which can demonstrate a company's determination to build an environmentally friendly enterprise and enhance its reputation. Thus, it is believed that green bond issuance can increase the degree of company involvement in CSR activities, leading to Hypothesis 3.

Hypothesis $3\left(\mathbf{H}_{3}\right)$ : Green bond issuance increases the participation of issuing companies in CSR activities. 


\section{Empirical Research and Discussion}

\subsection{Dataset}

Our data sample consists of 144 green bonds issued by 70 listed Chinese companies in mainland China from 2016 to 2019, of which 48 green bonds were issued on the Shanghai Stock Exchange, 34 were issued on the Shenzhen Stock Exchange, and 62 were issued in interbank markets. In terms of types of bonds, our sample includes 32 green corporate bonds, 68 green enterprise bonds, and 44 green financial bonds. No short-term financial bonds or medium-term notes were included. Data used in this paper were obtained from the Wind database. As the premier provider of Chinese financial information at home and abroad, data of Wind database are frequently quoted by Chinese and international media, in research reports and in academic papers. Detailed information about the Wind database can be found on the following website: http://www.wind.com.cn/NewSite/data.html.

Basic information regarding the issuing companies is shown in Table 1. Based on the level-I industry classification used in the Wind database, 30\% of the companies that issued green bonds between 2016 and 2019 were from the financial industry, and 70\% were from non-financial industry. In terms of company attributes, state-owned companies accounted for $44.3 \%$ of the total, while private and public companies accounted for $25.7 \%$ and $30.0 \%$, respectively.

Table 1. Basic information for the 70 sample companies.

\begin{tabular}{ccc}
\hline Classification & Type & Number \\
\hline Wind level-I industry classification & Non-financial industry & 49 \\
& Financial industry & 21 \\
Company attributes & Local state-owned & 21 \\
& Central state-owned & 10 \\
& Public & 21 \\
& Private & 18 \\
\hline
\end{tabular}

Basic information regarding the green bonds issued by the sample companies is shown in Table 2. As can be seen, the circulation of green bonds varied significantly, while the median and mean values of the bond duration and coupon rate were very similar. There was little variation in the green bond ratings, which were at least AA rated.

Table 2. Basic information for the 144 green bonds.

\begin{tabular}{ccccc}
\hline Bond Information & Circulation & Bond Duration & Coupon Rate & Bond Rating at Issue \\
\hline Mean & 2614.6 & 4.5625 & 4.5938 & - \\
Median & 1000 & 5 & 4.4950 & AAA \\
Maximum & 30000 & 10 & 7.5 & AAA \\
Minimum & 100 & 2 & 2.94 & AA \\
Standard deviation & 4885.2 & 1.5407 & 1.0558 & - \\
Skewness & 3.8239 & 0.9643 & 0.7989 & - \\
Kurtosis & 18.356 & 4.5735 & 3.3174 & - \\
\hline
\end{tabular}

\subsection{The Impact of Green Bond Issuance on Corporate Stock Prices}

In this paper, the date of the bond issuance announcement is considered to be the date of the occurrence of the event, and the event study approach is used to evaluate the reaction of the stock market to the issuance of green bonds. The announcement date is preferred over the issuance date because the announcement date is when new information is transferred to the market, while no new information is transferred to the market on the issuance date.

Selection of windows is related to the degree of the event's impact and the research objective, which should be determined in accordance with the specific situation. For example, when examining the 
impact of the announcement and the factors influencing the issuance of bonds, Chin and Abdullah [29] considered numerous windows including $[-20,-1],[-5,-1],[0,1],[1,5]$, and $[1,10]$. Considering that some information may be exposed in advance, the transaction date prior to the announcement of green bond issuance is also included in the event window; thus, the event window in this paper is $[-1,1]$. To analyze changes in stock prices before and after the event, time intervals of $[-20,-11]$ and $[-10,2]$ prior to the event window and time intervals of $[2,5],[6,10]$ and $[11,20]$ after the event window are used in this paper.

The time interval $[-250,-20]$ is used as the estimation window, and the market model is used to calculate abnormal returns. Cumulative abnormal returns are obtained by adding the daily abnormal returns over a particular time interval. Then, statistical tests are conducted with respect to the daily abnormal returns and cumulative abnormal returns to measure the significance of the event's impact. In order to show the calculation process in more detail and more clearly, we take "16 SPC G1" green bonds which were issued by Beijing SPC Environment Protection Tech Co., Ltd. (stock code: 002573 SZ, hereinafter referred to as SPC) and listed on the Shenzhen Stock Exchange as an example. The issuance announcement date of "16 SPC G1" green bonds is on 21 October 2016. We take the time interval from 250 days before the issue date to the 20 days before the issue date as the estimation window, which consists of 231 valid trading days from 15 May 2015 to 14 September 2016. According to Equation (1), the daily return rate of Shenzhen composite index (SZCI) was taken as the independent variable and the daily return rate of SPC as the dependent variable for general regression analysis. Intercept and slope of SPC's market model are obtained through regression. The results are shown in Equation (10), and the $R^{2}$ of the model is 0.3915 .

$$
E\left(R_{S P C, t}\right)=1.2803 R_{S Z C I, t}-0.004
$$

According to Equation (10), the expected return $(E R)$ of SPC in the event window $[-1,1]$, the time interval before the event window $[-20,-2]$, and the time interval after the event window $[2,20]$ can be predicted. According to Equation (2), the daily abnormal return $(A R)$ is the difference between the real daily return of SPC and its expected daily return. The results are shown in Table 3. According to Equation (3), the cumulative abnormal return of each green bond in a certain time interval can be obtained.

In this paper, the 70 green bond issuing companies were divided into 22 financial companies and 48 non-financial companies. The financial companies issued 44 green financial bonds, while the non-financial companies issued 80 green bonds (excluding two green bonds issued by companies that were not listed when the announcement of green bond issuance was made and 18 green bonds that were issued in situations where a company simultaneously issued more than one green bond). After repeating the above calculation process of "16 SPC G1" green bonds, calculating the daily average abnormal returns (AARs) and significance statistics of green finance bonds according to Equation (4) and Equation (6), we obtained results regarding the 44 green finance bonds issued by financial companies shown in Table A1 and Figure 7, and results regarding the 80 green financial bonds issued by non-financial companies shown in Table A2 and Figure 8. According to Equation (5) and Equation (7), the average cumulative abnormal returns (CAARs) and significance statistics of green finance bonds are calculated, and the results for the 44 green finance bonds issued by financial companies are shown in Table A3 and Figure 9, while those of the 80 green finance bonds issued by non-financial companies are shown in Table A4 and Figure 10. 
Table 3. Daily average abnormal returns of "16 SPC G1" green bonds issued by Beijing SPC Environment Protection (SPC).

\begin{tabular}{cccccc}
\hline Date $(\boldsymbol{t})$ & $\boldsymbol{E R}$ & $\boldsymbol{A R}$ & Date $(\boldsymbol{t})$ & $\boldsymbol{E R}$ & $\boldsymbol{A R}$ \\
\hline-20 & -0.00986 & -0.00552 & 1 & 0.01025 & -0.00178 \\
-19 & 0.00950 & -0.00729 & 2 & 0.00374 & 0.00074 \\
-18 & -0.00478 & 0.00864 & 3 & -0.00657 & 0.00040 \\
-17 & -0.00033 & -0.01184 & 4 & -0.00200 & 0.01375 \\
-16 & 0.00421 & -0.00254 & 5 & -0.01136 & 0.00578 \\
-15 & -0.01018 & 0.01352 & 6 & -0.00216 & -0.00175 \\
-14 & -0.03063 & -0.00836 & 7 & 0.01351 & -0.00345 \\
-13 & 0.00515 & -0.00631 & 8 & -0.00918 & -0.00593 \\
-12 & -0.00626 & -0.00651 & 9 & 0.00635 & -0.00466 \\
-11 & 0.00040 & 0.00890 & 10 & -0.00396 & 0.02072 \\
-10 & 0.00506 & -0.00390 & 11 & -0.00128 & 0.01885 \\
-9 & 0.02334 & -0.00273 & 12 & 0.00772 & -0.00826 \\
-8 & 0.00557 & -0.00841 & 13 & -0.00845 & 0.01820 \\
-7 & 0.00112 & -0.00910 & 14 & 0.01708 & -0.01385 \\
-6 & 0.00023 & -0.00886 & 15 & 0.00620 & -0.01267 \\
-5 & -0.00274 & 0.01194 & 16 & 0.00326 & 0.00749 \\
-4 & -0.01338 & -0.00218 & 17 & 0.00548 & 0.00092 \\
-3 & 0.01762 & -0.00319 & 18 & -0.00016 & -0.00677 \\
-2 & -0.00282 & 0.02661 & 19 & -0.00532 & -0.00166 \\
-1 & 0.00332 & 0.02045 & 20 & -0.00406 & -0.00351 \\
0 & -0.00596 & -0.00642 & & & \\
\hline
\end{tabular}

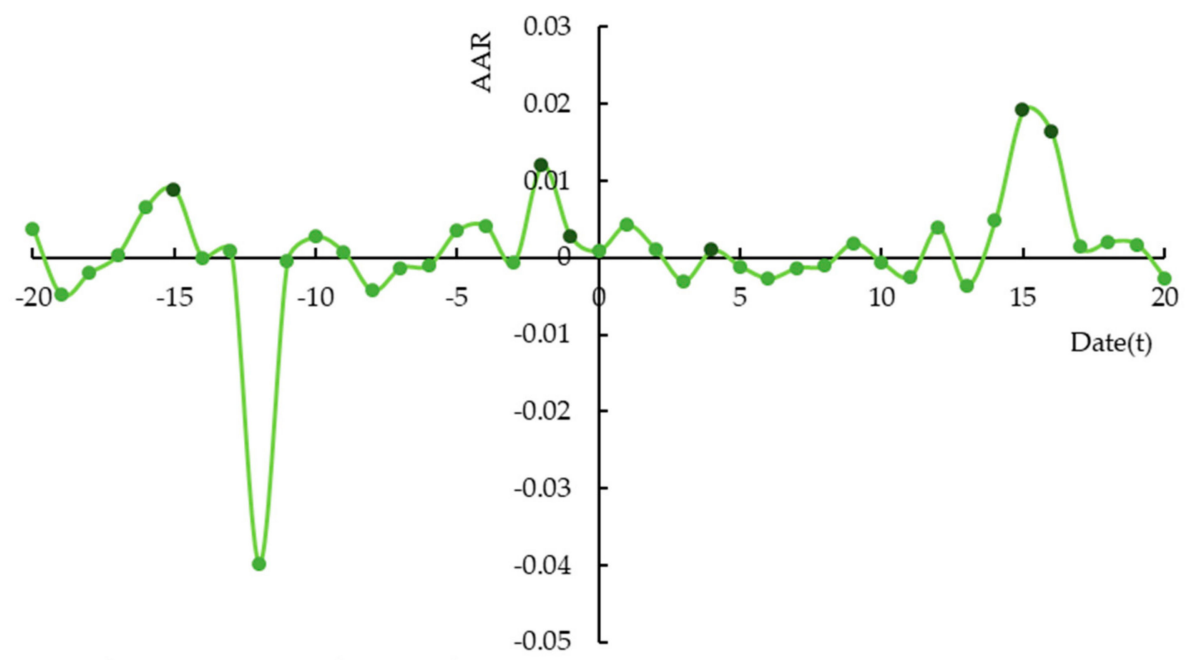

- indicates passing the significance test

Figure 7. Daily average abnormal returns of the 44 green financial bonds issued by financial companies.

The results shown in Table A1 and Figure 7 reveal the daily AARs and significance in the $[-20,20]$ window ( 41 days). The $A A R s$ are negative on 18 days and positive on 23 days. There is no significant change in the situation regarding negative AARs before and after the occurrence of the event. However, before the event occurs, AARs are significantly positive at the $1 \%$ level when $t=-1$ and at the $10 \%$ level when $t=-15$ and $t=-2$. On the day of occurrence, $A A R s$ are positive but not significant. After the event occurs, AARs are significantly positive at the $5 \%$ level when $t=4$ and at the $1 \%$ level when $t=15$ and $t=16$. After the event, AARs are significantly higher than before the event. This indicates that the stock market reacts positively to the issuance of green bonds by financial companies. The significantly positive values when $t=-2$ and $t=-1$ suggest that information may be disclosed in advance. 


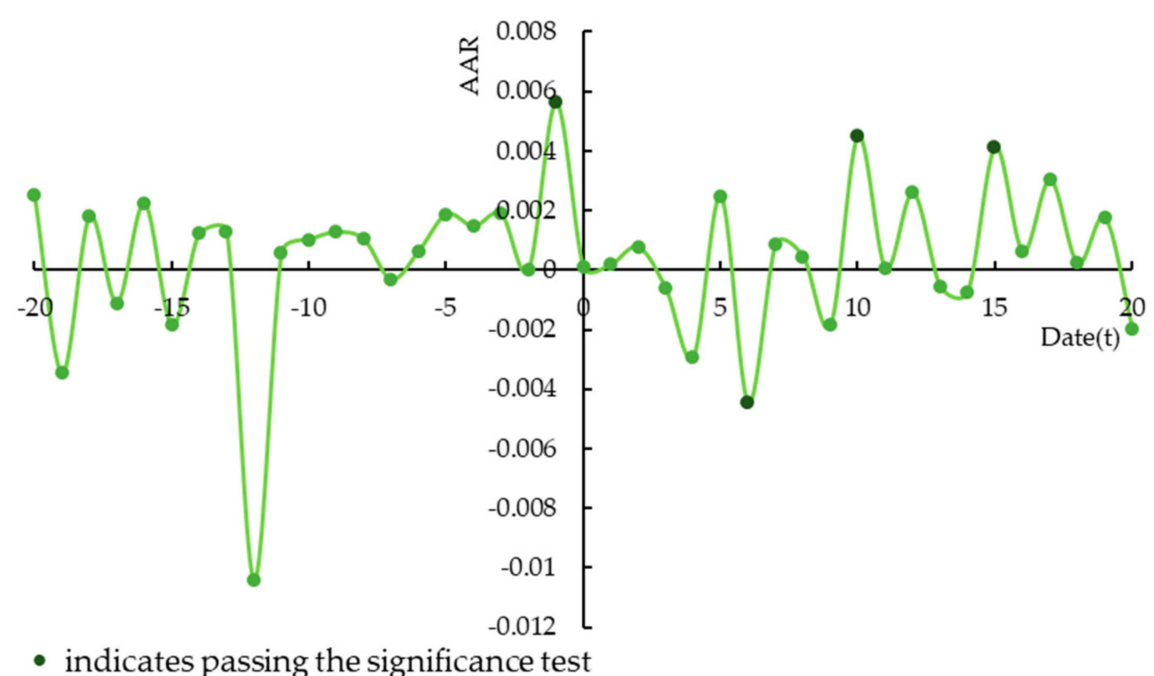

Figure 8. Daily average abnormal returns of the 80 green bonds issued by non-financial companies.

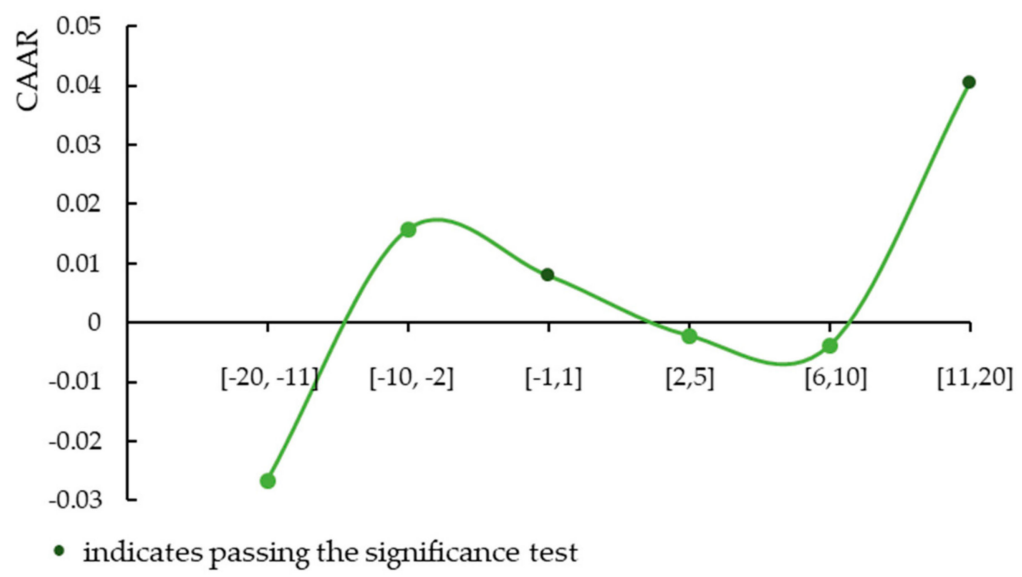

Figure 9. Daily cumulative average abnormal returns of the 44 green bonds issued by financial companies.

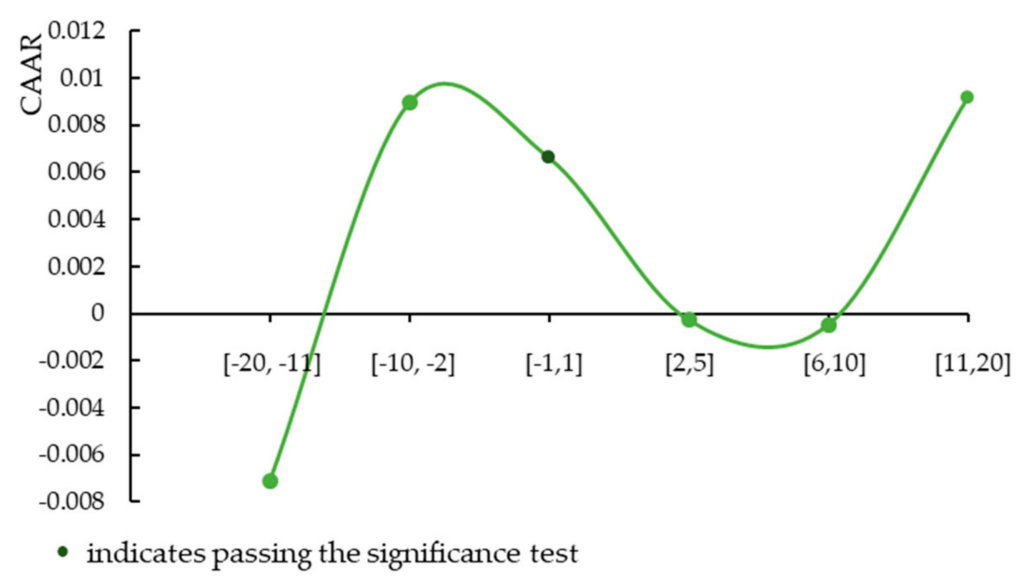

Figure 10. Daily cumulative average abnormal returns of the 80 green bonds issued by non-financial companies.

The results shown in Table A2 and Figure 8 are similar to those shown in Table A1 and Figure 7. However, in Table A2 and Figure 8, there is no significant $A A R$ value prior to the event (except for $t=-1$ ). After the event, when $t=6$, the $A A R$ value is significantly negative at the $5 \%$ level. When $t=10$ and $t=15, A A R s$ are significantly positive at both the $10 \%$ and $5 \%$ levels. The significance of $A A R s$ 
before the event is not obvious, while the significance of $A A R s$ after the event is higher than it is before the event, thus green bond issuance affects the stock market. In addition, the $A A R$ value is positive at the $5 \%$ level when $t=-1$. It can also be seen that information about green bond issuance may be disclosed before a formal announcement is made to the stock market, which may have a significant positive impact on the stock prices of the issuing companies.

Table A3 and Figure 9 show the CAARs and significance of the 44 green financial bonds issued by financial companies within the 41 -day time frame $([-20,11],[-10,-2],[-1,1],[2,5],[6,10]$, and $[11,20])$. Table $A 4$ and Figure 10 show the CAARs and significance of the 80 green bonds issued by non-financial companies within all the above time intervals. It can be seen from Figures 9 and 10 that $C A A R s$ are not significantly positive or negative prior to the event, while the CAAR is significantly positive at the $10 \%$ level in the $[-1,1]$ event window, indicating that green bond issuance has a positive impact on the stock prices of issuing companies. Thus, $H_{1}$ is supported. Similar to the findings of Haesen et al. [18] and Reboredo's study [31], we have demonstrated a link between the stock market and the bond market in China. The announcement of issuing green bonds can convey the company's intention to external stakeholders and thus achieve the purpose of attracting investors.

In contrast to the previous studies, we found that the effect is not satisfactory in the long run although green bonds have a positive announcement effect. Observing the window after the occurrence of the event, it can be seen that $C A A R s$ are negative in the $[2,5]$ and $[6,10]$ time intervals, but are not significant, indicating that the market appears to behave bearishly when positive events occur. Meanwhile, it also indicates that investors are not as enthusiastic about the good news associated with green bond issuance, and quickly lose interest [42]. However, it can be seen from the [11, 20] time interval that the $C A A R s$ of financial companies are significantly positive at the $10 \%$ level, while those of non-financial companies are positive but not significant. This suggests that although the attraction is not particularly sustainable, green bond issuance can attract some investors in the long run.

\subsection{The Impact of Green Bond Issuance on Corporate Performance}

To examine the impact of green bond issuance on corporate performance, three aspects of corporate performance were measured in this paper: Profitability, operational performance, and innovation capacity. Return on total assets $(R O A)$ was used to analyze profitability. This is the ratio of the total returns achieved by an enterprise over a given period to the enterprise's average total assets and represents overall profitability. Gross profit margin (GPM) is used to represent operational performance, and it is an important operational indicator for listed companies, as it reflects both the current profitability and potential profitability of a company. The ratio of research and development $(R \& D)$ to total operational income (short for $R D T O I)$ is used to represent innovation capacity, as this is the enterprise's key means of achieving core competitiveness and sustainable development. It includes expenses incurred during $R \& D$ of products, technologies, materials, processes, and standards, and represents the enterprise's level of investment in innovation.

To provide more accurate results, financial companies were not included in the analysis of financial performance. The research object was the 43 non-financial companies that issued green bonds from 2016 to 2018. Based on the relevant research on PSM method, a non-alternative one-to-one nearest neighbor matching method was selected. Considering that companies issued green bonds every year from 2016 to 2018, this paper used the year-by-year matching method to find a matching control group for each year's treatment group, which is similar to the relevant studies conducted by Blundell and Dias [71] and Heyman et al. [72]

Specifically, companies corresponding to these 43 companies that had issued straight bonds were identified by setting specific matching conditions. There are two levels of matching conditions. The bond level includes the year of issuance (YOIS) and the bond term (BTERM), while the company level includes the industry (INDU), corporate size (SIZE), asset/liability ratio (ALRTO), property ratio (PRTO), and total asset turnover ratio (TATURN). Companies were individually matched based on conditions at these two levels. In the matching process, in order to verify the reliability of the matching 
results, the equilibrium hypothesis of score matching is tested in this paper. Only the equilibrium test results for $R O A$ are shown in Figure 11. Information on both the treatment group and the control group for $R O A$ is shown in Table 4.

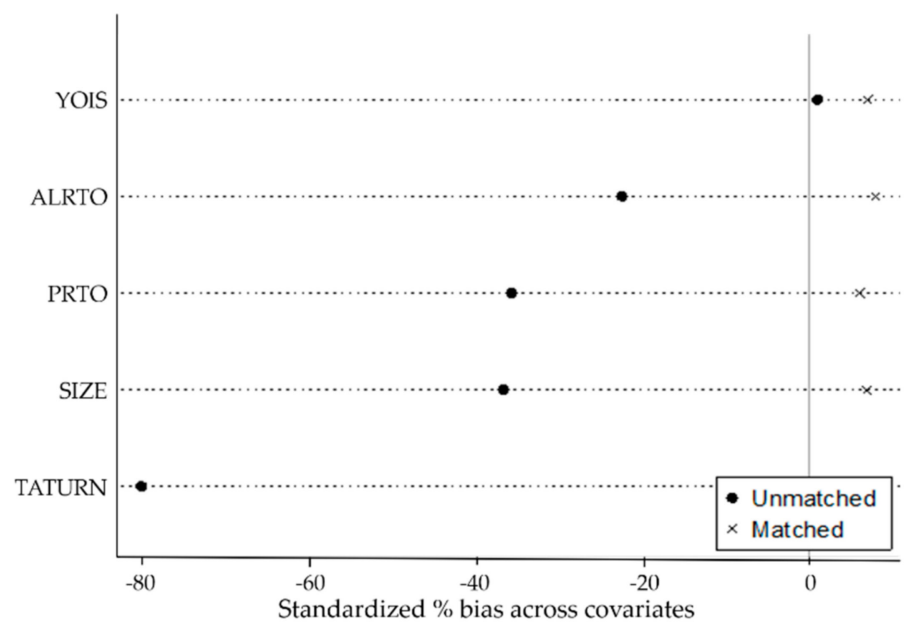

Figure 11. Equilibrium Test Results using propensity score matching (PSM) for return on total assets (ROA).

It can be seen from Figure 11 that the standard deviations prior to matching are significant, while all the points revert to 0 after matching, indicating the selected variables and match method is reasonable. At the same time, it can be seen from Table 4 that the indexes for the control group and the treatment group are relatively close after matching. It indicates that no significant differences in control variables existed between the treatment group and the control group after matching. In other words, given the propensity score $p(X)$, the processing is independent of the matching variable. Therefore, the samples obtained after matching guarantee the randomness of sample processing and the reliability of the estimated results in this paper.

Table 4. Descriptive statistics for the experimental and control groups after PSM.

\begin{tabular}{ccccccc}
\hline \multirow{3}{*}{ Mean } & & ROA & SIZE & ALRTO & PRTO & TATURN \\
\hline \multirow{4}{*}{ Median } & Treated & 7.1581 & 62.67 & 58.17 & 1.6598 & 0.3654 \\
& Control & 6.5332 & 47.15 & 56.71 & 1.5803 & 0.4863 \\
& Treated & 6.1585 & 15 & 59.75 & 1.4847 & 0.3199 \\
& Control & 5.8247 & 24 & 57.95 & 1.3782 & 0.3844 \\
\multirow{3}{*}{ Maximum } & Treated & 106.1 & 979 & 82.53 & 4.7259 & 1.906 \\
& Control & 28.84 & 515 & 89.18 & 8.2487 & 2.4869 \\
\multirow{3}{*}{ Standard deviation } & Treated & -13.11 & 0 & 0 & 0 & 0 \\
& Control & -10.60 & 0 & 0 & 0 & 0 \\
& Treated & 7.1136 & 27.15 & 13.74 & 0.8950 & 0.2253 \\
& Control & 4.4029 & 68.53 & 13.73 & 0.9792 & 0.3474 \\
\hline
\end{tabular}

Note: $R \widehat{O A}$ is the ratio of the total returns achieved by an enterprise over a given period to the enterprise's average total assets and represents overall profitability. SIZE represents the total assets of the company, ALRTO is a comprehensive index to evaluate the debt level of the company, PRTO reflects the relative relationship between capital provided by creditors and capital provided by shareholders, TATURN is an important financial ratio that measures the efficiency of an enterprise's asset management.

Regression analysis was carried out for the 86 listed companies using the DID method. A dual-difference model of the impact of green bond issuance on companies' $R O A$ is established, as shown in Equation (11).

$$
\begin{aligned}
R O A_{i, t}= & \text { Cons }+\beta_{0} \times \text { Treated } * \text { Post }_{i, t}+\beta_{1} \text { SIZE }_{i, t}+\beta_{2} \text { ALRTO }_{i, t}+\beta_{3} \text { PRTO }+ \\
& \beta_{4} \text { TATURN }+u_{i, t}+\tau_{i, t}+\varepsilon_{i, t}
\end{aligned}
$$


The data are panel data that may contain heterogeneity in both individual (companies) and time dimensions. To ensure that regression analysis provides the same results as a pre-post comparison of means, we considered the double-fixed effects model of time and individual. We regressed the model according to Equation (11). SIZE $i_{i, t}, A L R T O_{i, t}, P R T O_{i, t}$, TATURN $_{i, t}$ are the control variables, $u_{i, t}$ and $\tau_{i, t}$ represent the double-fixed effect model of individual fixed effect and time fixed effect, respectively. The interaction term is the focus of our research. "Treated" and "Post" are virtual variables. In relation to Treated, the value of 1 indicates the treatment group, while the value of 0 indicates the control group. As for Post, the value of 1 indicates the time after the green bond issuance, while the value of 0 indicates the time before the green bond issuance. The value of 1 for Treated*Post indicates the performance of companies in the treatment group after green bonds issuance. The results of DID analysis are shown in Table 5.

It can be seen from Table 5 that the coefficient for the item Treated ${ }^{*}$ Post is positive and passes the significance test, indicating that green bond issuance has a positive impact on companies' ROA. In other words, sufficient capital is raised for corporate projects through green bond issuance, and corporate investments achieve adequate returns.

Analyses of the impact of green bond issuance on operational performance and innovation capacity were carried out using the same method. The results are shown in Tables 6 and 7, respectively.

Table 5. Empirical results using PSM and differences-in-differences (DID) for the impact of green bond issuance on corporate return on total assets $(R O A)$.

\begin{tabular}{cccc}
\hline Variable & Coef. & T-test & $p\left(^{*}\right)$ \\
\hline Treated ${ }^{*}$ Post & 0.0116 & 1.86 & $0.064^{*}$ \\
SIZE & 0.0097 & 4.66 & $0.000^{* * *}$ \\
ALRTO & -0.0813 & -2.24 & $0.025^{* *}$ \\
PRTO & -0.3358 & -0.63 & 0.527 \\
TATURN & 5.5224 & 7.26 & $0.000^{* * *}$ \\
Cons & 10.04 & 6.63 & $0.000^{* * *}$ \\
R-squared & 0.1727 & $F(5,596)$ & 24.88 \\
Obs & 258 & Prob $>F$ & 0.000 \\
\hline \multicolumn{4}{c}{ Note: ${ }^{*} p<0.05 ;{ }^{* *} p<0.01 ;{ }^{* * *} p<0.001}$.
\end{tabular}

Table 6. Empirical results using PSM and DID for the impact of green bond issuance on corporate gross profit margin (GPM).

\begin{tabular}{clcc}
\hline Variable & Coef. & T-test & $p\left(^{*}\right)$ \\
\hline Treated ${ }^{*}$ Post & 1.6048 & 1.86 & $0.064^{*}$ \\
SIZE & 0.0095 & 1.77 & $0.078^{*}$ \\
ALRTO & -0.1854 & -1.97 & $0.050^{* *}$ \\
PRTO & -6.7612 & -4.90 & $0.000^{* * *}$ \\
TATURN & 5.2703 & 7.72 & $0.000^{* * *}$ \\
Cons & 9.3393 & 9.43 & $0.000^{* * *}$ \\
R-squared & 0.1442 & $F(5,596)$ & 20.09 \\
Obs & 258 & Prob $>F$ & 0.000 \\
\hline \multicolumn{4}{c}{ Note: ${ }^{*} p<0.05 ;{ }^{* *} p<0.01 ; * * *<<0.001}$.
\end{tabular}

It can be seen from Tables 6 and 7 that the coefficients for Treated ${ }^{*}$ Post are positive and pass the significance test. This indicates that green bond issuance can improve operational performance and innovation capacity. Comparing the results shown in Table 5, Table 6, and Table 7, it can be seen that the impact of control variables on corporate $R O A$ and GPM are generally consistent, indicating that larger companies with a sound asset structure (ALRTO and PRTO) and faster capital turnover (TATURN) have greater marketing capacity, and thus can achieve better returns on investment. However, the impact of control variables on corporate RDTOI differs, mainly in relation to corporate size (SIZE) and the 
asset/liability ratio (ALRTO). This might be related to the type of company that issues green bonds. In general, green bond issuance has a positive impact on financial performance. Thus, $\mathrm{H}_{2}$ is supported.

Table 7. Empirical results using PSM and DID for the impact of green bond issuance on corporate ratio of research and development to total operational income (RDTOI).

\begin{tabular}{clcc}
\hline Variable & Coef. & T-test & $p\left(^{*}\right)$ \\
\hline Treated $^{*}$ Post & 0.8124 & 3.75 & $0.000^{* * *}$ \\
SIZE & -0.0019 & -2.61 & $0.009^{* * *}$ \\
ALRTO & 0.0322 & 2.54 & $0.011^{* *}$ \\
PRTO & -0.5769 & -3.09 & $0.002^{* * *}$ \\
TATURN & 1.3190 & 4.94 & $0.000^{* * *}$ \\
Cons & -0.3374 & -0.69 & 0.488 \\
R-squared & 0.0878 & $F(5,596)$ & 11.47 \\
Obs & 258 & Prob $>F$ & 0.000 \\
\hline \multicolumn{4}{c}{ Note: ${ }^{*} p<0.05 ;{ }^{* *} p<0.01 ; * * *<0.001}$.
\end{tabular}

To further verify the impact of green bond issuance on financial performance, alternative variables (return on invested capital (ROIC), net profit margin on sales $(S A M)$, and year-on-year growth of $R \& D$ expenses $(R D G)$ ) were used to represent profitability, operational performance, and innovation capacity, respectively. The results of these analyses using PSM and DID are shown in Table 8.

Table 8. Empirical Results using PSM and DID for the impact of green bond issuance on corporate return on invested capital (ROIC), net profit margin on sales (SAM), and year-on-year growth of research and development expenses $(R D G)$.

\begin{tabular}{|c|c|c|c|c|c|c|}
\hline \multirow{2}{*}{ Variable } & \multicolumn{2}{|c|}{ ROIC } & \multicolumn{2}{|c|}{$S A M$} & \multicolumn{2}{|c|}{$R D G$} \\
\hline & Coef. & $T$-test & Coef. & $T$-test & Coef. & $T$-test \\
\hline Treated ${ }^{*}$ Post & 0.2458 & 0.32 & 1.0760 & 0.90 & 1.8114 & $1.30^{* *}$ \\
\hline SIZE & 0.0011 & $4.24^{* * *}$ & 0.0120 & $2.98^{* * *}$ & 0.0014 & 0.05 \\
\hline ALRTO & -0.0691 & -1.52 & -0.0218 & -0.31 & 0.8675 & $1.87^{*}$ \\
\hline PRTO & -0.6554 & -0.98 & -3.5139 & $-3.42^{* * *}$ & -10.89 & $-1.61^{*}$ \\
\hline TATURN & 8.8482 & $9.25^{* * *}$ & 4.1149 & $9.61^{* * *}$ & 15.72 & $1.62^{*}$ \\
\hline Cons & 7.7797 & $4.47^{* * *}$ & 22.54 & $8.42^{* * *}$ & -26.76 & $-1.51^{*}$ \\
\hline$R$-squared & 0.1913 & & 0.1793 & & 0.1129 & \\
\hline Obs & 258 & & 258 & & 258 & \\
\hline$F(5,596)$ & 23.46 & & 26.03 & & 12.57 & \\
\hline
\end{tabular}

It can be seen from Table 8 that the impact of Treated Post on ROIC, SAM, and RDG remains positive, and the sign and significance of the control variables are basically consistent with those shown in Tables 5-7. The impact of green bond issuance on profitability and operational performance is weaker in the results shown in Table 8 than in those shown in Tables 5 and 6, mainly because ROIC stresses the need for returns on investment, while it has only been three years since the introduction of green bonds in China. Thus, it might be the case that capital raised through the issuance of green bonds has not yet been invested in projects, or some projects have not yet been completed, resulting in the finding that green bond issuance does not appear to have had a significantly positive impact on ROIC. There is a positive correlation between SAM and net profit, but a negative correlation between $S A M$ and sales revenue. Companies must achieve a sufficiently large GPM to enable the improvement of $S A M$. In other words, companies must achieve greater net profits while increasing sales income so that $S A M$ can be maintained or improved. Thus, more rigorous conditions and impactive modes are required, such as raising prices and sales volumes, while reducing costs. This paper mainly examines corporate bonds and enterprise bonds, with emphasis on the long-term impact on corporate profits, and thus a positive short-term impact on $S A M$, may not be significant. 
In general, our results fall somewhere between the findings by Zerbib and Flammer. Zerbib's results suggest that investors attracted by the "green" label do not seem to promote green bond development $[10,16]$, while Flammer demonstrated that green bond issuance can indeed generate positive economic benefits and improve corporate financial performance [15]. Our findings suggest that the issuance of green bonds in China is not only a form of greenwashing, it also can improve the financial performance of enterprises. As time goes on and the number of mature green bonds increases, the significance of green bonds in promoting corporate profitability, financial performance and innovation ability will also be improved.

\subsection{The Impact of Green Bond Issuance on CSR}

CSR reports on Chinese listed companies published on hexun.com were used to analyze the impact of green bond issuance on CSR. The data contained in these reports included responsibility for shareholders, employees, suppliers, and customers; the environment; and society. There are 13 level-II indexes (including environmental governance and value of contribution) and 37 level-III indexes (including environmental awareness, environmental management system certification, investment in environmental protection, number of sewerage types, number of types of energy saving, ratio of income tax to total profits, and public welfare donations). Normally, the shareholder responsibility weight accounts for $30 \%$ of the total, with $15 \%$ allocated for employees, $15 \%$ for suppliers and customers, $20 \%$ for the environment, and $20 \%$ for society.

Companies that issued green bonds and straight bonds were individually matched using PSM, and the PSM equilibrium test results for CSR are shown in Figure 12.

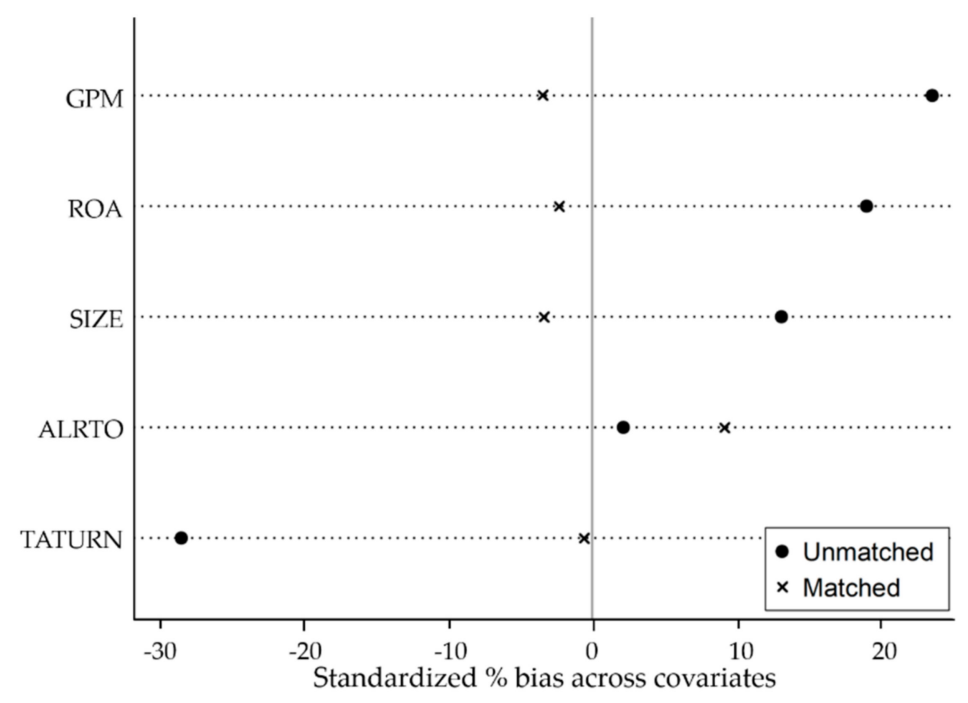

Figure 12. Equilibrium test results using PSM for corporate social responsibility (CSR).

It can be seen from Figure 12 that there are significant standard deviations prior to matching, while all the points are around 0 after matching, indicating that the matching is effective.

A dual-difference model of the impact of green bond issuance on companies' CSR is established, as shown in Equation (12).

$$
\begin{aligned}
\operatorname{CSR}_{i, t}= & \text { Cons }+\beta_{0} \times \text { Treated }^{*} \text { Post }_{i, t}+\beta_{1} \text { Treated }_{i, t}+\beta_{2} \text { ROA }_{i, t}+\beta_{3} \text { SIZE }_{i, t} \\
& +\beta_{4} \text { ALRTO }+\beta_{5} G P M+u_{i}+\tau_{i}+\varepsilon_{i, t}
\end{aligned}
$$

The results of the DID analysis are shown in Table 9. 
Table 9. Empirical results using PSM and DID for the impact of green bond issuance on corporate CSR.

\begin{tabular}{cccc}
\hline Variable & Coef. & T-test & $\boldsymbol{p}\left(^{*}\right)$ \\
\hline Treated $^{*}$ Post & 6.6270 & 2.32 & $0.021^{* *}$ \\
Treated & 5.7855 & 2.75 & $0.006^{* * *}$ \\
ROA & 0.8111 & 0.60 & 0.006 \\
SIZE & 0.1345 & 2.05 & $0.087^{*}$ \\
ALRTO & -0.2019 & 0.09 & 0.930 \\
GPM & 1.0048 & 1.32 & 0.190 \\
Cons & 2.7862 & 6.18 & $0.000^{* * *}$ \\
R-squared & 0.1453 & $F(4,475)$ & 14.32 \\
Obs & 246 & Prob $>F$ & 0.000 \\
\hline
\end{tabular}

Note: ${ }^{*} p<0.05 ;{ }^{* *} p<0.01 ;{ }^{* * *} p<0.001$.

It can be seen from Table 9 that the coefficients of Treated and Treated*Post are positive and pass the significance test. The coefficient of Treated shows that the CSR scores of companies issuing green bonds are higher than those of companies issuing straight bonds. In other words, companies that issue green bonds shoulder a greater CSR load than those issuing straight bonds. In addition, the coefficient of Treated*Post indicates that following the issuance of bonds, the increase in CSR scores of companies that issue green bonds is greater than that of companies issuing straight bonds. In other words, green bond issuance improves participation in CSR activities (including responsibilities relating to shareholders, creditors, and the government, as well as those relating to environmental protection and the public). This result supports $\mathrm{H}_{3}$.

Considering the increasing CSR of the companies after the green bonds issuance, there may be several reasons. Firstly, as for the issuance motive, green bonds are usually issued in order to participate in the green or environmental protection project. The project itself is useful to the society and the environment, so the activities of supporting green projects can promote CSR level of participation. Secondly, as for the issuance costs, the issuance of green bonds reduces the financing costs and improves the efficiency of using resources, and thus helps company to provide products and services for the society. Thirdly, as for the issuance significance, the issuance of green bonds is conducive to establishing a good corporate image. By disclosing the use of the raised funds on relevant websites, companies continuously release positive information, which is conducive to the promotion of corporate reputation and social responsibility.

To further investigate the impact of green bond issuance on CSR, a robustness test was conducted using the event study approach. There is only one set of CSR rating data, and thus annual data are used, and the years of green bond issuance are used as event windows. Taking green bonds issued in 2016 as an example, 2016 is the event window, and 2012-2015 is the event observation period and the estimation window. Some companies' ratings are not included in the CSR reports on Chinese listed companies published on hexun.com, and so these companies were excluded from the sample, leaving 41 listed companies for the robustness test. Normal CSR scores of the event window are the expected scores that were predicted by the CSR values of the estimation window. Abnormal CSR scores were calculated based on the real and normal numerical values of the 41 companies, and the results are shown in Table 10. RCSR denotes the real CSR value, ACSR denotes the abnormal CSR value, and AACSR denotes the average abnormal CSR value, using the arithmetic mean of the ACSR of all companies. 
Table 10. Empirical results of robustness tests of the impact of green bond issuance on CSR using the event study approach.

\begin{tabular}{|c|c|c|c|}
\hline Number. & YOIS & RCSR & ACSR \\
\hline 1 & 2016 & 78.85 & 39.82 \\
\hline 2 & 2016 & 21.02 & 6.89 \\
\hline 3 & 2016 & 30.34 & 24.66 \\
\hline 4 & 2016 & 20.78 & 1.72 \\
\hline 5 & 2016 & 63.95 & 50.42 \\
\hline 6 & 2016 & 29.71 & 22.23 \\
\hline 7 & 2016 & 66.65 & 49.06 \\
\hline 8 & 2016 & 29.25 & 0.24 \\
\hline 9 & 2016 & 29.08 & 1.26 \\
\hline 10 & 2016 & 18.8 & 1.61 \\
\hline 11 & 2016 & 24.25 & 0.51 \\
\hline 12 & 2016 & 71.58 & 71.58 \\
\hline 13 & 2016 & 23.53 & -5.83 \\
\hline 14 & 2016 & 31.43 & -2.74 \\
\hline 15 & 2016 & 63.5 & 80.87 \\
\hline 16 & 2017 & 23.09 & 2.12 \\
\hline 17 & 2017 & 33.01 & -13.81 \\
\hline 18 & 2017 & 15.85 & -3.32 \\
\hline 19 & 2017 & 25.12 & -0.11 \\
\hline 20 & 2017 & 27.8 & -1.15 \\
\hline 21 & 2017 & 22.71 & 0.05 \\
\hline 22 & 2017 & 24.14 & 19.20 \\
\hline 23 & 2017 & 11.48 & -3.49 \\
\hline 24 & 2017 & 25.82 & 0.73 \\
\hline 25 & 2017 & 24.14 & -4.23 \\
\hline 26 & 2017 & 27.13 & 3.22 \\
\hline 27 & 2017 & 34.43 & -9.00 \\
\hline 28 & 2017 & 27.56 & -22.70 \\
\hline 29 & 2017 & 20.56 & -4.46 \\
\hline 30 & 2017 & 19.6 & 8.84 \\
\hline 31 & 2017 & 30.89 & 20.11 \\
\hline 32 & 2017 & 19.6 & -32.06 \\
\hline 33 & 2017 & 15.16 & -3.11 \\
\hline 34 & 2018 & 11.71 & -1.65 \\
\hline 35 & 2018 & 20.27 & -26.99 \\
\hline 36 & 2018 & 23.15 & -12.83 \\
\hline 37 & 2018 & 27.49 & 2.74 \\
\hline 38 & 2018 & 21.35 & -4.98 \\
\hline 39 & 2018 & 20.75 & -21.57 \\
\hline 40 & 2018 & 24.62 & -7.40 \\
\hline 41 & 2018 & 31.2 & 19.45 \\
\hline$A A C S R$ & 5.9976 & $T$-test* & $1.6391^{*}$ \\
\hline
\end{tabular}

Table 10 shows the real and abnormal CSR values for the 41 companies. The AACSR passes the significance test, indicating that the $A C S R$ value is significantly different from 0 . It also indicates that CSR ratings changed significantly after green bond issuance. The AACSR and T-test values are positive, indicating that CSR ratings improved significantly after issuance. Therefore, the hypothesis that green bond issuance improves the participation of issuing companies in CSR activities is reasonable, and thus $H_{3}$ is supported. 


\section{Conclusions}

This paper examines the green bond market in China, which has attracted increasing attention in recent years. Data for Chinese listed companies, which have been issuing green bonds since 2016, are analyzed to determine the impact of green bond issuance on the issuing companies. The economic and environmental benefits of the green bonds issuance are also examined. Specifically, the impact of announcements of green bond issuance on companies' stock prices and the impact of green bond issuance on companies' performance and CSR are analyzed. The results indicate that announcements of green bond issuance have a positive effect on companies' stock prices. In other words, green bonds definitely attract some investors, although the interest stimulated by the prospect of increased environmental protection is not particularly sustainable. In addition, green bond issuance plays an active role in improving companies' profitability, operational performance, and innovation capacity. The results show that green bond issuance is not merely virtue signaling in relation to environmental protection and sustainable development but can produce significant economic and environmental benefits. Furthermore, as the quantity of maturing green bonds increases, the significance of the role of green bonds in improving companies' profitability, operational performance, and innovation capacity will increase. Finally, green bond issuance increases companies' CSR activities to some extent, in line with investment approaches (e.g., environmental, social, and corporate governance) that are becoming increasingly popular.

Previous studies have shown that China's green bond market requires continuous improvement, and green bond standards should be strictly implemented to accelerate the alignment of China's market with international community expectations. In terms of information disclosure, the theoretical design of green bonds and related trading systems should be enhanced to enable external supervision and control of green bonds and ensure the smooth progress of green projects. In terms of CSR, the independence and integrity of third-party rating institutions should be guaranteed, and more companies should be included.

It can be seen that the green bond market in China emerged in recent years, thus our paper could only use data starting from 2016 to 2019. The short time period and relatively small sample size could affect the accuracy of some results. In addition, when collecting data on China's green bonds, the standards used for China's green bond indexes compiled through the joint efforts of the China Central Depository \& Clearing Co., Ltd and the China Energy Conservation and Environmental Protection Group Consulting Co., Ltd were taken into consideration rather than the international standard. Therefore, with the passage of time, when the green bond has more perfect data, the research in this paper can be further developed. This paper on green bonds and CSR participation is an interesting and novel topic in China. Therefore, we will further study the relationship between green bonds and CSR participation in the future.

Author Contributions: Conceptualization, X.Z. Methodology, writing-review and editing, supervision, X.Z.; conceptualization, data curation, writing — original draft preparation, Y.C.

Funding: This research was funded by the National Natural Science Foundation of China, grant number 71771023; the National Social Science Foundation of China, grant number 17BGL052.

Conflicts of Interest: The authors declare no conflict of interest. 


\section{Appendix A}

Table A1. Daily average abnormal returns of the 44 green financial bonds issued by financial companies.

\begin{tabular}{cccccc}
\hline Date $(t)$ & AAR & T-test $\left(t^{*}\right)$ & Date $(t)$ & $A A R$ & $T$-test $\left(t^{*}\right)$ \\
\hline-20 & 0.00381 & 0.63508 & 1 & 0.00425 & 0.73091 \\
-19 & -0.00480 & -1.22404 & 2 & 0.00106 & 0.30077 \\
-18 & -0.0020 & -0.47875 & 3 & -0.00302 & -1.11760 \\
-17 & 0.00035 & 0.11074 & 4 & 0.00091 & $2.22268^{* *}$ \\
-16 & 0.00655 & 1.23567 & 5 & -0.00113 & -0.39807 \\
-15 & 0.00880 & $1.94908^{*}$ & 6 & -0.00272 & -0.72894 \\
-14 & -0.00010 & -0.02980 & 7 & -0.00134 & -0.34915 \\
-13 & 0.00087 & 0.13580 & 8 & -0.00105 & -0.28833 \\
-12 & -0.03974 & -0.98098 & 9 & 0.00187 & 0.70100 \\
-11 & -0.00035 & -0.09759 & 10 & -0.00063 & -0.14795 \\
-10 & 0.00270 & 0.48162 & 11 & -0.00247 & -0.59477 \\
-9 & 0.00066 & 0.23533 & 12 & 0.00384 & 0.95946 \\
-8 & -0.0042 & -0.82436 & 13 & -0.00368 & -1.32495 \\
-7 & -0.00133 & -0.24387 & 14 & 0.00483 & 1.06008 \\
-6 & -0.00099 & -0.24297 & 15 & 0.01910 & $4.99309^{* * *}$ \\
-5 & 0.00350 & 0.79764 & 16 & 0.01623 & $3.99305^{* * *}$ \\
-4 & 0.00408 & 0.8632 & 17 & 0.00146 & 0.46571 \\
-3 & -0.00062 & -0.26467 & 18 & 0.00208 & 0.55460 \\
-2 & 0.01197 & $1.75452^{*}$ & 19 & 0.00172 & 0.36388 \\
-1 & 0.00275 & $5.47721^{* * *}$ & 20 & -0.00266 & -0.12423 \\
0 & 0.00091 & 0.22573 & & & \\
\hline
\end{tabular}

Note: ${ }^{* * *}$, and ${ }^{* * *}$ denote significance at the $10 \%, 5 \%$, and $1 \%$ level, respectively.

Table A2. Daily average abnormal returns of the 80 green bonds issued by non-financial companies.

\begin{tabular}{cccccc}
\hline Date $(t)$ & AAR & $T$-test $\left(t^{*}\right)$ & Date $(t)$ & $A A R$ & $T$-test $\left(t^{*}\right)$ \\
\hline-20 & 0.00250 & 1.16577 & 1 & 0.00020 & 0.09171 \\
-19 & -0.00345 & -1.64815 & 2 & 0.00077 & 0.31319 \\
-18 & 0.00179 & 0.72975 & 3 & -0.00061 & -0.31123 \\
-17 & -0.00110 & -0.55986 & 4 & -0.00290 & -1.23226 \\
-16 & 0.00224 & 0.92869 & 5 & 0.00248 & 1.11099 \\
-15 & -0.00184 & -0.89269 & 6 & -0.00444 & $-2.59634^{* *}$ \\
-14 & 0.00124 & 0.57362 & 7 & 0.00086 & 0.35855 \\
-13 & 0.00130 & 0.51788 & 8 & 0.00046 & 0.22690 \\
-12 & -0.01039 & -0.96962 & 9 & -0.00183 & -0.96700 \\
-11 & 0.00059 & 0.29384 & 10 & 0.00448 & $1.90599^{*}$ \\
-10 & 0.00102 & 0.43327 & 11 & 0.00006 & 0.02912 \\
-9 & 0.00128 & 0.65417 & 12 & 0.00259 & 1.41050 \\
-8 & 0.00103 & 0.45671 & 13 & -0.00055 & -0.35990 \\
-7 & -0.00031 & -0.14467 & 14 & -0.00072 & -0.36526 \\
-6 & 0.00064 & 0.35041 & 15 & 0.00411 & $2.39813^{* *}$ \\
-5 & 0.00187 & 0.95190 & 16 & 0.00062 & 0.33560 \\
-4 & 0.00147 & 0.68413 & 17 & 0.00303 & 1.48275 \\
-3 & 0.00188 & 0.86037 & 18 & 0.00022 & 0.11732 \\
-2 & 0.00003 & 0.01190 & 19 & 0.00175 & 0.89641 \\
-1 & 0.00561 & $2.55034^{* *}$ & 20 & -0.00198 & -0.32078 \\
0 & 0.00009 & 0.03870 & & & \\
\hline
\end{tabular}

Note: ${ }^{*}{ }^{* *}$, and ${ }^{* * *}$ denote significance at the $10 \%, 5 \%$, and $1 \%$ level, respectively. 
Table A3. Daily cumulative average abnormal returns of the 44 green bonds issued by financial companies.

\begin{tabular}{ccc}
\hline Date $(t)$ & CAAR & T-test $\left(t^{*}\right)$ \\
\hline$[-20,-11]$ & -0.02660 & -0.70052 \\
{$[-10,-2]$} & 0.01569 & 1.05648 \\
{$[-1,1]$} & 0.00793 & $1.85503^{*}$ \\
{$[2,5]$} & -0.00218 & -0.36383 \\
{$[6,10]$} & -0.00389 & -0.31811 \\
{$[11,20]$} & 0.04046 & $1.99128^{*}$ \\
*** denote significance at the $10 \%, 5 \%$, and $1 \%$ level, respectively.
\end{tabular}

Table A4. Daily cumulative average abnormal returns of the 80 green bonds issued by non-financial companies.

\begin{tabular}{ccc}
\hline Date $(t)$ & CAAR & T-test $\left(t^{*}\right)$ \\
\hline$[-20,-11]$ & -0.00711 & -0.63682 \\
{$[-10,-2]$} & 0.00893 & 1.37026 \\
{$[-1,1]$} & 0.00661 & $1.69833^{*}$ \\
{$[2,5]$} & -0.00026 & -0.06241 \\
{$[6,10]$} & -0.00046 & -0.09164 \\
{$[11,20]$} & 0.00916 & 1.03434
\end{tabular}

Note: ${ }^{*}, * *$ and ${ }^{* * *}$ denote significance at the $10 \%, 5 \%$, and $1 \%$ level, respectively.

\section{References}

1. Cuaresma, J.C.; Palokangas, T.; Tarasyev, A. Green Growth and Sustainable Development; Springer: Berlin/Heidelberg, Germany, 2013. [CrossRef]

2. Serfati, C. Globalised finance-dominated accumulation regime and sustainable development. Int. J. Sustain. Dev. 2000, 3, 40-62. [CrossRef]

3. Scholtens, B.; Cerin, P.; Hassel, L. Sustainable development and socially responsible finance and investing. Sustain. Dev. 2010, 16, 137-140. [CrossRef]

4. Kudratova, S.; Huang, X.; Zhou, X. Sustainable project selection: Optimal project selection considering sustainability under reinvestment strategy. J. Clean. Prod. 2018, 203, 469-481. [CrossRef]

5. NGFS. A Call for Action, Climate Change as a Source of Financial Risk, Bank De France. 2019. Available online: https://www.dnb.nl/en/about-dnb/co-operation/network-greening-financial-system/index.jsp (accessed on 7 November 2019).

6. The People's Bank of China. Guidelines for Establishing the Green Financial System; The People's Bank of China: Beijing, China, 2016. Available online: http://sg.cufe.edu.cn/info/1231/5043.htm (accessed on 7 November 2019).

7. Bank, W. What are Green Bonds? (English); World Bank Group: Washington, DC, USA, 2015. Available online: http://documents.worldbank.org/curated/en/400251468187810398/What-are-greenbonds (accessed on 31 August 2019).

8. Ehlers, T.; Packer, F. Green Bond Finance and Certification. Bis Quarterly Review. 2017. Available online: https://ssrn.com/abstract=3042378 (accessed on 31 August 2019).

9. Hachenberg, B.; Schiereck, D. Are green bonds priced differently from conventional bonds? J. Asset Manag. 2018, 19, 371-383. [CrossRef]

10. Zerbib, O.D. Is there a green bond premium? The yield differential between green and conventional bonds. J. Bank. Financ. 2019, 98, 39-60. [CrossRef]

11. Nanayakkara, M.; Colombage, S. Do investors in green bond market pay a premium? Global evidence. Appl. Econ. 2019, 2, 1-13. [CrossRef]

12. Wulandari, F.; Schäfer, D.; Stephan, A.; Sun, C. The impact of liquidity risk on the yield spread of green bonds. Financ. Res. Lett. 2018, 27, 53-59. 
13. Berensmann, K.; Dafe, F.; Lindenberg, N. Green Bonds: Taking Off the Rose-Coloured Glasses. Deutsches Institut für Entwicklungspolitik. 2016. Available online: https://www.die-gdi.de/briefing-paper/article/ green-bonds-taking-off-the-rose-coloured-glasses (accessed on 31 August 2019).

14. Queen, I.T. Green Bonds and Climate Change: State of the Art or Artful Dodge? ProQuest Dissertations and Theses. 2016. Available online: http://rave.ohiolink.edu/etdc/view?acc_num=miami1470352085 (accessed on 31 August 2019).

15. Flammer, C. Corporate Green Bonds; Social Science Electronic Publishing: London, UK, 2018. Available online: https://ssrn.com/abstract=3125518 (accessed on 31 August 2019). [CrossRef]

16. Zerbib, O.D. The effect of pro-environmental preferences on bond prices: Evidence from green bonds. J. Bank. Financ. 2019, 98, 39-60. [CrossRef]

17. Gebhardt, W.R.; Hvidkjaer, S.; Swaminathan, B. Stock and bond market interaction: Does momentum spill over? J. Finan. Econ. 2005, 75, 651-690. [CrossRef]

18. Haesen, D.; Houweling, P.; Zundert, J.V. Momentum spillover from stocks to corporate bonds. J. Bank. Financ. 2017, 79, 28-41. [CrossRef]

19. Kumar, P.C.; Tsetsekos, G.P. Managerial ownership and stock price reaction to bond downgrades. Appl. Finan. Econ. 1993, 3, 357-364. [CrossRef]

20. Zhou, X.-G.; Ding, Y.-F.; Lu, M. Study on bond selection with interaction of indices under fuzzy conditions. J. Algorithms Comput. Technol. 2018, 12, 376-386. [CrossRef]

21. Dutordoir, M.; Hui, L.; Liu, F.H.; Verwijmeren, P. Convertible bond announcement effects: Why is japan different? J. Corp. Financ. 2016, 37, 76-92. [CrossRef]

22. Kapoor, A.K.; Pope, R.A. The relationship between corporate debt issuance and changes in systematic risk. J. Financ. Strateg. Decis. 1997, 10, 13-22.

23. Lewis, C.M.; Rogalski, R.J.; Seward, J.K. The long-run performance of firms that issue convertible debt: An empirical analysis of operating characteristics, analyst forecasts, and risk effects. J. Corp. Financ. 2001, 10, 447-474. [CrossRef]

24. Li, H.; Liu, H.; Siganos, A. A comparison of the stock market reactions of convertible bond offerings between financial and non-financial institutions: Do they differ? Int. Rev. Financ. Anal. 2016, 45, 356-366. [CrossRef]

25. Abhyankar, A.; Dunning, A. Wealth effects of convertible bond and convertible preference share issues: An empirical analysis of the uk market. J. Bank. Financ. 1999, 23, 1043-1065. [CrossRef]

26. Cheng, W.; Visaltanachoti, N.; Kesayan, P. A stock market reaction following convertible bond issuance: Evidence from japan. Int. J. Bus. 2005, 10, 323-340.

27. Martel, M.C.V.; Padron, Y.G. Debt and information content: Evidence in the spanish stock market. Int. Res. J. Financ. Econ. 2006, 4, 202-208.

28. Miller, M.K. Dividend policy under asymmetric information. J. Financ. 1985, 40, 1031-1051. [CrossRef]

29. Chin, S.K.; Abdullah, N.A.H. Announcements effect of corporate bond issuance and its determinants. Contemp. Econ. 2013, 7, 5-17. [CrossRef]

30. Mathews, J.A.; Kidney, S. Financing climate-friendly energy development through bonds. Dev. South. Afr. 2012, 29, 337-349. [CrossRef]

31. Reboredo, J.C. Green bond and financial markets: Co-movement, diversification and price spillover effects. Energy Econ. 2018, 74, 38-50. [CrossRef]

32. Baulkaran, V. Stock market reaction to green bond issuance. J. Asset Manag. 2019, 20, 331-340. [CrossRef]

33. Pham, L. Is it risky to go green? A volatility analysis of the green bond market. J. Sustain. Financ. Investig. 2016, 6, 263-291. [CrossRef]

34. Chiesa, M.; Barua, S. The surge of impact borrowing: The magnitude and determinants of green bond supply and its heterogeneity across markets. J. Sustain. Financ. Investig. 2018, 1-24. [CrossRef]

35. Nelson, K. Finding and implementing projects that reduce waste. In Industrial Ecology and Global Change; Socolow, R., Andrews, C., Berkhout, F., Thomas, V., Eds.; Cambridge University Press: New York, NY, USA, 1994.

36. Panayotou, T.; Zinnes, C. Free-lunch economics for industrial ecologists. In Industrial Ecology and Global Change; Socolow, R., Andrews, C., Berkhout, F., Thomas, V., Eds.; Cambridge University Press: New York, NY, USA, 1994.

37. Esty, D.; Porter, M. Industrial ecology and competitiveness: Strategic implications for the firm. J. Ind. Ecol. 1998, 2, 35-43. [CrossRef] 
38. Reinhardt, F. Market failure and the environmental policies of firms. J. Ind. Ecol. 1999, 3, 9-21. [CrossRef]

39. Porter, M.; van der Linde, C. Green and competitive. Harv. Bus. Rev. 1995, 5, 121-134.

40. Hart, S.L.; Ahuja, G. Does it pay to be green? An empirical examination of the relationship between emission reduction and firm performance. Bus. Strategy Environ. 1996, 5, 30-37. [CrossRef]

41. King, A.A.; Lenox, M.J. Does it really pay to be green? An empirical study of firm environmental and financial performance. J. Ind. Ecol. 2010, 5, 105-116. [CrossRef]

42. Horvathova, E. Does enviromental performance affect financial performance? Ameta-analysis. Ecolog. Econ. 2011, 70, 52-59. [CrossRef]

43. Hart, S.L. Beyond greening: Strategies for a sustainable world. Harv. Bus. Rev. 1997, 75, 66-76.

44. Miroshnychenko, I.; Barontini, R.; Testa, F. Green practices and financial performance: A global outlook. J. Clean. Prod. 2017, 147, 340-351. [CrossRef]

45. Aguilera-Caracuel, J.; Ortiz-De-Mandojana, N. Green innovation and financial performance: An institutional approach. Organ. Environ. 2013, 26, 365-385. [CrossRef]

46. Carroll, A.B. A three-dimensional conceptual model of corporate performance. Acad. Manag. Rev. 1979, 4, 497-505. [CrossRef]

47. Clarkson, M.B.E. A stakeholder framework for analyzing and evaluating corporate social performance. Acad. Manag. J. 1995, 20, 92-118.

48. Beurden, P.; Gossling, T. The worth of values-A literature review on the relation between corporate social and financial performance. J. Bus. Ethics 2008, 82, 407-424. [CrossRef]

49. Graves, S.; Waddock, S.A. Institutional owners and corporate social performance. Acad. Manag. J. 1994, 18, 303-317.

50. Johnson, R.A.; Greening, D.W. The effects of corporate governance and institutional ownership types on corporate social performance. Acad. Manag. J. 1999, 42, 564-576.

51. Freeman, R.E.; Liedtka, J. Corporate social responsibility: A critical approach. Bus. Horiz. 1991, 34, 92-98. [CrossRef]

52. Flammer, C. Corporate social responsibility and shareholder reaction: The environmental awareness of investors. Acad. Manag. J. 2013, 56, 758-781. [CrossRef]

53. Lu, C.W.; Chueh, T.S. Corporate social responsivity and information asymmetry. J. Appl. Financ. Bank 2015, 5, 105-122.

54. Cho, S.Y.Y.; Lee, C.; Pfeiffer, R.J., Jr. Corporate social responsibility performance and information asymmetry. J. Account. Public Policy 2013, 32, 71-83. [CrossRef]

55. Wang, Y.; Zhi, Q. The role of green finance in environmental protection: Two aspects of market mechanism and policies. Energy Procedia 2016, 104, 311-316. [CrossRef]

56. Huang, J.; Wei, H.; Zhu, G. The effect of corporate social responsibility on cost of corporate bond: Evidence from china. Emerg. Mark. Financ. Trade 2018, 54, 255-268. [CrossRef]

57. Chiang, W.C.; Shang, J.; Li, S. Broad bond rating change and irresponsible corporate social responsibility activities. Adv. Account. 2017, 39, 32-46. [CrossRef]

58. Mcwilliams, A.; Siegel, D.; Teoh, S.H. Issues in the use of the event study methodology: A critical analysis of corporate social responsibility studies. Organ. Res. Methods 1999, 2, 340-365. [CrossRef]

59. Martin, C.M.; Moran, D. Impact of the ftse4good index on firm price: An event study. J. Environ. Manag. 2007, 82, 529-537. [CrossRef]

60. Kolari, J.W.; Pynnönen, S. Event study testing with cross-sectional correlation of abnormal returns. Rev. Financ. Stud. 2010, 23, 3996-4025. [CrossRef]

61. Agrawal, J.; Kamakura, W.A. The economic worth of celebrity endorsers: An event study analysis. J. Mark. 1995, 59, 56-62. [CrossRef]

62. Michalek, J.; Ciaian, P.; Pokrivcak, J. The impact of producer organizations on farm performance: The case study of large farms from slovakia. Food Policy 2018, 75, 80-92. [CrossRef]

63. Zhang, Y.J.; Peng, Y.L.; Ma, C.Q.; Shen, B. Can environmental innovation facilitate carbon emissions reduction? Evidence from china. Energy Policy 2017, 100, 18-28. [CrossRef]

64. Song, Y.C.; Lie, H.Y. Does heterogeneity matter to the direct effect of fdi on firm performance? The case of Indian firms. Int. J. Emerg. Mark. 2018, 13, 1876-1906. [CrossRef]

65. Borin, A.; Mancini, M. Foreign direct investment and firm performance: An empirical analysis of italian firms. Rev. World Econ. 2015, 152, 1-28. [CrossRef] 
66. Li, G.; He, Q.; Shao, S.; Cao, J. Environmental non-governmental organizations and urban environmental governance: Evidence from china. J. Environ. Manag. 2018, 206, 1296-1307. [CrossRef]

67. Abadie, A. Semiparametric difference-in-differences estimators. Rev. Econ. Stud. 2005, 72, 1-19. [CrossRef]

68. Fan, Y.; Manzanares, C.A. Partial identification of average treatment effects on the treated through difference-in-differences. Econom. Rev. 2017, 36, 1057-1080. [CrossRef]

69. Bouasone, S.; Masaru, I. Effectiveness of Irrigation Access on Sticky Rice Productivity: Evidence from Lao PDR. Sustainability 2019, 11, 5839. [CrossRef]

70. Cui, J.; Jo, H.; Na, H. Does corporate social responsibility affect information asymmetry? J. Bus. Ethics 2018, 148, 1-24. [CrossRef]

71. Blundell, R.; Dias, M.C. Evaluation methods for non-experimental data. Fisc. Stud. 2000, 21, 427-468. [CrossRef]

72. Heyman, F.; Fredrik, S.; Patrik, G.T. Is there really a foreign ownership wage premium? Evidence from matched employer-employee data. J. Int. Econ. 2007, 73, 355-376. [CrossRef]

(C) 2019 by the authors. Licensee MDPI, Basel, Switzerland. This article is an open access article distributed under the terms and conditions of the Creative Commons Attribution (CC BY) license (http://creativecommons.org/licenses/by/4.0/). 